\title{
Hydrogen sulphide alleviates iron deficiency by promoting iron availability and plant hormone levels in Glycine max seedlings
}

Juan Chen ${ }^{1,2^{*}}$, Ni-Na Zhang ${ }^{1}$, Qing Pan ${ }^{1}$, Xue-Yuan Lin ${ }^{1}$, Zhouping Shangguan ${ }^{1}$, Jian-Hua Zhang ${ }^{2,3}$ and Ge-Hong Wei ${ }^{1^{*}}$

\begin{abstract}
Background: Hydrogen sulphide $\left(\mathrm{H}_{2} \mathrm{~S}\right)$ is involved in regulating physiological processes in plants. We investigated how $\mathrm{H}_{2} \mathrm{~S}$ ameliorates iron ( $\mathrm{Fe}$ ) deficiency in soybean (Glycine max L.) seedlings. Multidisciplinary approaches including physiological, biochemical and molecular, and transcriptome methods were used to investigate the $\mathrm{H}_{2} \mathrm{~S}$ role in regulating Fe availability in soybean seedlings.

Results: Our results showed that $\mathrm{H}_{2} \mathrm{~S}$ completely prevented leaf interveinal chlorosis and caused an increase in soybean seedling biomass under Fe deficiency conditions. Moreover, $\mathrm{H}_{2} \mathrm{~S}$ decreased the amount of root-bound apoplastic Fe and increased the Fe content in leaves and roots by regulating the ferric-chelate reductase (FCR) activities and Fe homeostasis- and sulphur metabolism-related gene expression levels, thereby promoting photosynthesis in soybean seedlings. In addition, $\mathrm{H}_{2} \mathrm{~S}$ changed the plant hormone concentrations by modulating plant hormone-related gene expression abundances in soybean seedlings grown in Fe-deficient solution. Furthermore, organic acid biosynthesis and related genes expression also played a vital role in modulating the $\mathrm{H}_{2} \mathrm{~S}$ mediated alleviation of Fe deficiency in soybean seedlings.
\end{abstract}

Conclusion: Our results indicated that Fe deficiency was alleviated by $\mathrm{H}_{2} \mathrm{~S}$ through enhancement of Fe acquisition and assimilation, thereby regulating plant hormones and organic acid synthesis in plants.

Keywords: Hydrogen sulphide $\left(\mathrm{H}_{2} \mathrm{~S}\right)$, Iron assimilation, Iron deficiency, Organic acid, Plant hormones, Soybean (Glycine max)

\footnotetext{
* Correspondence: chenjuan@nwsuaf.edu.cn; weigehong@nwsuaf.edu.cn 'State Key Laboratory of Soil Erosion and Dryland Farming on the Loess Plateau, Northwest A\&F University, Yangling, Shaanxi 712100, P.R. China Full list of author information is available at the end of the article
}

(c) The Author(s). 2020 Open Access This article is licensed under a Creative Commons Attribution 4.0 International License, which permits use, sharing, adaptation, distribution and reproduction in any medium or format, as long as you give appropriate credit to the original author(s) and the source, provide a link to the Creative Commons licence, and indicate if changes were made. The images or other third party material in this article are included in the article's Creative Commons licence, unless indicated otherwise in a credit line to the material. If material is not included in the article's Creative Commons licence and your intended use is not permitted by statutory regulation or exceeds the permitted use, you will need to obtain permission directly from the copyright holder. To view a copy of this licence, visit http://creativecommons.org/licenses/by/4.0/. The Creative Commons Public Domain Dedication waiver (http://creativecommons.org/publicdomain/zero/1.0/) applies to the data made available in this article, unless otherwise stated in a credit line to the data. 


\section{Background}

Iron $(\mathrm{Fe})$ is an essential micronutrient for both the growth and development of plants and the health life of human beings. $\mathrm{Fe}$, as a universal cofactor, plays an vital role in photosynthesis, respiration, hormone biosynthesis, and morphogenesis cellular enzymatic reactions and the growth and developmental processes of plants [1, 2]. Although Fe is rich in soil, it is often difficult for crops to uptake and utilize because of the low solubility of oxidized Fe(III) in compound form in alkaline soil [3]. Additionally, Fe deficiency causes the interveinal chlorosis of leaf and the impairment of chlorophyll biosynthesis, and further influences photosynthesis and the growth and development in plants [4]. Therefore, the uptake and availability of Fe is closely related to the plant growth and crop productivity.

Fe absorption, transport and circulation can strictly control Fe abundance in plant cells $[5,6]$. Plants have evolved two distinct mechanisms for obtaining Fe from the rhizosphere to adapt to Fe-deficient environments. Strategy I plant species (all dicots and non-graminaceous monocots) respond to Fe deficiency in at least three steps: (1) the release of protons to acidify the rhizosphere by $\mathrm{H}^{+}$-ATPase, (2) the induction of ferric chelate reductase activity mediated by ferric-chelate reductase (FCR), which catalyses the reduction of ferric iron chelates to $\mathrm{Fe}^{2+}$, and (3) the uptake of $\mathrm{Fe}^{2+}$ by the high-affinity metal transporter IRT1 (ironregulated transporter 1 ), which is responsible for transporting the $\mathrm{Fe}^{2+}$ into root cells $[3,7,8]$. Strategy II plant species (graminaceous monocots) respond to Fe deficiency in four steps: (1) phytosiderophore (muginetic acid, MAs) biosynthesis within roots, (2) phytosiderophore (PS) secretion into the rhizosphere, (3) solubilization of insoluble Fe in soils through the chelation of PSs, and (4) uptake of the ferric-phytosiderophore complex by roots $[9,10]$.

Plants have evolved a series of physiological and morphological responses to maintain the Fe dynamic balance in Fe-deficient soils. For example, the basic helix-loophelix (bHLH), as a transcriptional regulatory element, has been identified to regulate the adaption of Fe deficiency in plants [11]. Fe deficiency can rapidly induce high expression levels of $b H L H s$, while subsequent $\mathrm{Fe}$ re-supplementation can inhibit $b H L H$ expression [12]. Additionally, ferritin is an iron storage protein that is localized in plastids and plays roles during development and under stress conditions. Moreover, ferritin Fe in leaves may serve as a preliminary pool for building up of Fe-containing proteins, and ferritin accumulation maintains Fe homeostasis and protects against iron-mediated oxidative stress and abiotic stress [11, 13]. In Arabidopsis thaliana, ferritins are encoded by a multigene family [14]. Among the ferritins, the expression level of AtFer1 is increased in response to Fe application [15].

Several plant hormones are particularly involved in the process of Fe deficiency responses [11, 16]. For instance, auxin plays vital roles in the morphological changes in the root system in response to Fe deficiency, and Fe deficiency causes an increase in the auxin synthesis [17]. Fe deficiency significantly induces the over-production of ethylene, and the transcriptional regulation of a series of Fe acquisition genes is modulated by ethylene $[18,19]$. Abscisic acid (ABA) alleviates Fe deficiency-induced chlorosis by promoting Fe transport and redistribution from roots to shoots [20]. In addition, three other hormones, including cytokinin (CTK), jasmonate (JA), and brassinosteroids (BRs), can negatively regulate Fe deficiency responses in plants [21, 22]. For instance, both exogenous CTK and methyl-JA treatments obviously inhibit the expression levels of Fe acquisition-related genes in plants, such as $I R T, F R O 2$, and FIT [21, 23]. Similarly, BRs, as steroid hormones, play an important role in the plant response to various environmental stresses. Wang et al. [24] found that a BR biosynthesis-defective mutant displays a greater tolerance to Fe deficiency than wildtype plants. Shen et al. [25] reported that SA activates Fe translocation to adapt to the Fe-deficient environment. However, whether other signalling molecule interactions with plant hormones are involved in regulating Fe assimilation is still not clear.

Recently, many studies have shown that hydrogen sulphide $\left(\mathrm{H}_{2} \mathrm{~S}\right)$, as a signalling molecule similar to nitric oxide (NO) and carbon monoxide (CO), plays an important role in various biological processes in plants. For instance, previous studies have revealed that $\mathrm{H}_{2} \mathrm{~S}$ promotes seed germination [26], alleviates oxidative damage against copper and aluminium stress [27, 28], counteracts chlorophyll loss [29], and alleviates osmotic stress by enhancing antioxidant enzyme stress in sweet potato seedling leaves [30]. Furthermore, salinity toxicity is alleviated by $\mathrm{H}_{2} \mathrm{~S}$ in plants [31,32]. $\mathrm{H}_{2} \mathrm{~S}$ induces drought tolerance by enhancing polyamines and sugar biosynthesis in Spinacia oleracea seedlings [33]. In addition, zinc $(\mathrm{Zn})$ toxicity, cadmium $(\mathrm{Cd})$ toxicity, and heat stress are alleviated by $\mathrm{H}_{2} \mathrm{~S}$ [34-37]. $\mathrm{H}_{2} \mathrm{~S}$ induces stomatal closure and participates in abscisic acid (ABA)dependent signalling pathway in guard cells [38]. Our previous study has shown that $\mathrm{H}_{2} \mathrm{~S}$ enhances photosynthesis in Spinacia oleracea seedlings [39].

Previously published studies have revealed that NO and $\mathrm{CO}$ regulates Fe metabolism by affecting FCR activities and $\mathrm{Fe}$ assimilation-related gene expression in plants $[11,18,40]$. Interestingly, $\mathrm{H}_{2} \mathrm{~S}$ improves strategy II plant (Zea mays) adaptation to Fe deficiency by increasing Fe uptake in roots and transport in leaves [10]. However, in contrast to strategy II plant, whether $\mathrm{H}_{2} \mathrm{~S}$ is involved in regulating strategy I plant responses to $\mathrm{Fe}$ deficiency is still unclear.

The aim of the present work was to investigate how $\mathrm{H}_{2} \mathrm{~S}$ ameliorate Fe deficiency in soybean seedlings. Our 
hypothesis was that $\mathrm{H}_{2} \mathrm{~S}$ has a beneficial influence on soybean seedlings in response to Fe deficiency. To test this hypothesis, we investigated the effect of $\mathrm{H}_{2} \mathrm{~S}$ on $\mathrm{Fe}$ storage and availability in the roots of soybean seedlings using physiological and transcriptomics methods.

\section{Results}

NaHS inhibits dry biomass and chlorophyll loss in irondeficient Glycine max plants

$\mathrm{NaHS}$ was used as the exogenous $\mathrm{H}_{2} \mathrm{~S}$ donor as described by Hosoki et al. [41]. NaHS successfully suppressed the symptoms of Fe deficiency in soybean plants treated with the NaHS -free nutrient solution and $1 \mu \mathrm{M}$ Fe(III)-EDTA for $15 \mathrm{~d}$ (Fig. 1a). By contrast, plants grown without NaHS became severely chlorotic. However, under Fe-sufficient $(+\mathrm{Fe})$ conditions, the effect of $\mathrm{NaHS}$ on the phenotype of soybean growth was not significant (Fig. 1a). After $15 \mathrm{~d}$ of treatments, the dry weight of leaf, stem and root were strongly enhanced by $\mathrm{NaHS}$ in Fe-deficient (-Fe) plants compared with those that had not been treated with NaHS, in contrast to the -Fe plants, where $\mathrm{H}_{2} \mathrm{~S}$ did not affect the dry weight of + Fe plants (Table 1). Moreover, the chlorophyll content significantly decreased after $15 \mathrm{~d}$ of treatment, but NaHS significantly inhibited the Fe deficiency-induced chlorophyll loss in soybean leaves (Table 1). Moreover, under $+\mathrm{Fe}$ conditions, NaHS also significantly promoted the chlorophyll content of soybean leaves (Table 1). To

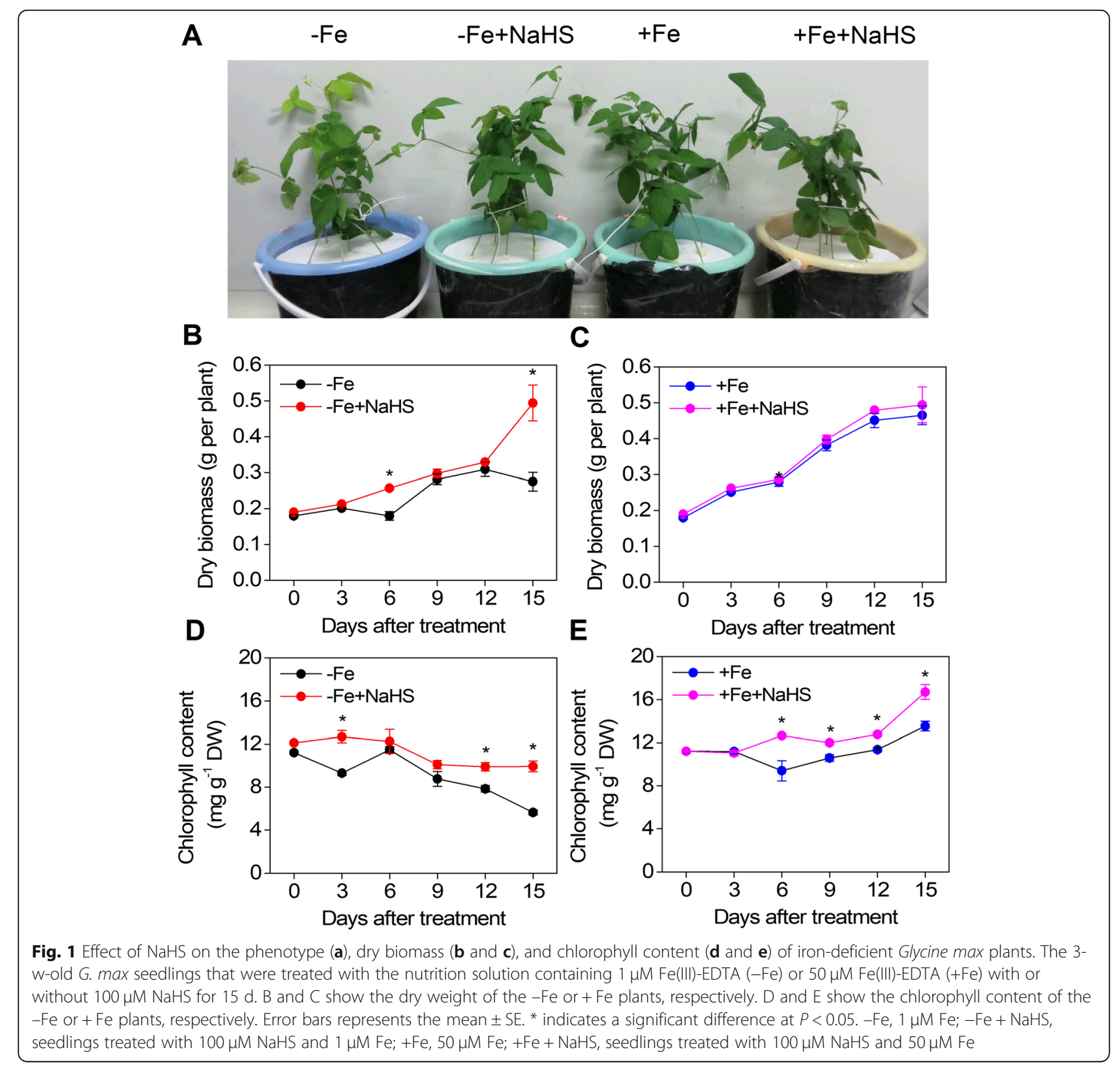


Table 1 Effect of NaHS on chlorophyll content, dry biomass, and Fe concentration of iron-deficient Glycine max plants. The 3-w-old Glycine max seedlings were treated with the nutrition solution containing $1 \mu \mathrm{M}$ Fe(III)-EDTA or $50 \mu \mathrm{M}$ Fe(III)-EDTA with or without $100 \mu \mathrm{M}$ NaHS for 15 days. Error bars represents the mean \pm SE. Different letters indicate significant differences with $P<0.05$. $-\mathrm{Fe}$, $1 \mu \mathrm{M} \mathrm{Fe} ;-\mathrm{Fe}+\mathrm{NaHS}$, seedlings treated with $100 \mu \mathrm{M} \mathrm{NaHS}$ and $1 \mu \mathrm{M} \mathrm{Fe}$ +Fe, $50 \mu \mathrm{M} \mathrm{Fe} ;+\mathrm{Fe}+\mathrm{NaHS}$, seedlings treated with $100 \mu \mathrm{M}$ $\mathrm{NaHS}$ and $50 \mu \mathrm{M} \mathrm{Fe}$

\begin{tabular}{|c|c|c|c|c|c|c|c|}
\hline \multirow[t]{2}{*}{ Treatments } & \multirow{2}{*}{$\begin{array}{l}\text { Chlorophyll content } \\
\text { (mg g-1 FW) }\end{array}$} & \multicolumn{3}{|c|}{ Dry biomass (g per plant) } & \multicolumn{3}{|c|}{ Fe concentration $\left(\mathrm{mg} \mathrm{g}^{-1} \mathrm{DW}\right)$} \\
\hline & & Leaf & Stem & Root & Leaf & Stem & Root \\
\hline$-\mathrm{Fe}$ & $0.564 \pm 0.022 \mathrm{~d}$ & $0.106 \pm 0.004 \mathrm{~b}$ & $0.118 \pm 0.008 b$ & $0.046 \pm 0.001 \mathrm{~b}$ & $0.377 \pm 0.005 c$ & $0.202 \pm 0.005 c$ & $0.309 \pm 0.013 \mathrm{~d}$ \\
\hline$-\mathrm{Fe}+\mathrm{NaHS}$ & $0.992 \pm 0.051 c$ & $0.186 \pm 0.007 \mathrm{a}$ & $0.209 \pm 0.002 \mathrm{a}$ & $0.080 \pm 0.002 \mathrm{a}$ & $0.490 \pm 0.028 b$ & $0.244 \pm 0.021 b$ & $0.399 \pm 0.022 c$ \\
\hline$+\mathrm{Fe}$ & $1.353 \pm 0.046 b$ & $0.174 \pm 0.006 \mathrm{a}$ & $0.214 \pm 0.024 \mathrm{a}$ & $0.084 \pm 0.008 \mathrm{a}$ & $0.696 \pm 0.033 \mathrm{a}$ & $0.425 \pm 0.035 \mathrm{a}$ & $0.855 \pm 0.113 b$ \\
\hline$+\mathrm{Fe}+\mathrm{NaHS}$ & $1.670 \pm 0.068 \mathrm{a}$ & $0.181 \pm 0.005 a$ & $0.195 \pm 0.003 a$ & $0.083 \pm 0.001 \mathrm{a}$ & $0.634 \pm 0.041 \mathrm{a}$ & $0.394 \pm 0.018 \mathrm{a}$ & $1.805 \pm 0.107 \mathrm{a}$ \\
\hline
\end{tabular}

distinguish the role of $\mathrm{H}_{2} \mathrm{~S}$ from that of other sulphurcontaining derivatives and sodium, a series of sulphurand sodium-containing chemicals including $\mathrm{NaHS}, \mathrm{Na}_{2} \mathrm{~S}$, $\mathrm{Na}_{2} \mathrm{SO}_{4}, \quad \mathrm{Na}_{2} \mathrm{SO}_{3}, \quad \mathrm{NaHSO}_{4}, \mathrm{NaHSO}_{3}$, and $\mathrm{NaAC}$ $(100 \mu \mathrm{M})$ were used to treat soybean seedlings under iron deficiency conditions. After Fe deficiency treatment for 15 $\mathrm{d}$, the chlorophyll content did not cause a great increase in the $\mathrm{Na}^{+}$or other sulphur-containing compounds treatments compared with the NaHS treatment (Fig. S1).

Furthermore, to further elucidate the mechanism of the $\mathrm{H}_{2} \mathrm{~S}$-mediated amelioration of Fe deficiency stress timecourse experiments were conducted to study the dynamics of relevant physiological indexes. For instance, under $-\mathrm{Fe}$ conditions, total dry biomass had an obvious increase in the NaHS-treated plants under -Fe condition for $15 \mathrm{~d}$ (Fig. 1b), and keep approximately the same high concentration of chlorophyll $\left(1.2 \mathrm{mg} \mathrm{g}^{-1} \mathrm{FW}\right)$ under only $+\mathrm{Fe}$ treatment (Fig. 1d and e). However, under + Fe conditions, NaHS did not significantly change the dry biomass during all the treatment period, but the chlorophyll content was obviously increased by NaHS (Fig. 1c and e).

\section{NaHS treatment increases iron accumulation in Glycine max plants}

The Fe concentration in the NaHS-treated plants was obviously higher than in the controls (plants not treated with $\mathrm{NaHS}$ ) under -Fe conditions for $15 \mathrm{~d}$ (Table 1). For example, the Fe concentration increased by $30 \%$ in the leaves of NaHS-treated plants compared with those not treated with NaHS (Table 1). Moreover, a more than two-fold increase was found in the roots of NaHS-treated plants under $+\mathrm{Fe}$ conditions, but the Fe concentration in leaves and stems was not affected by NaHS (Table 1).

\section{NaHS modulates the $\mathrm{pH}$ of root bathing solution, FCR} activity, and root apoplastic Fe content to iron acquisition in Glycine max plants

During the whole period of $-\mathrm{Fe}$ treatment, the $\mathrm{pH}$ of the root bathing solution drastically decreased from 7.3 to 6.1, but the NaHS-treated plants only slowly decreased compared with those in the - Fe treatment alone (Fig. 2a).
However, under $+\mathrm{Fe}$ treatment, the $\mathrm{pH}$ of bathing solution showed significant differences between the $+\mathrm{Fe}$ and $+\mathrm{Fe}+\mathrm{NaHS}$ treatments at both 9 and $12 \mathrm{~d}$, but no significant difference was found at any other time points were (Fig. $2 \mathrm{~b}$ ). The FCR activity varied greatly depending on the NaHS treatments during the whole period of $-\mathrm{Fe}$ treatment (Fig. 2c). During the first $3 \mathrm{~d}$, the FCR activity became significantly higher in the NaHS-treated plants than in the - Fe treatment alone (Fig. 2c). However, from the 6th $\mathrm{d}$ to the end of the experiment, the FCR activity gradually decreased in the NaHS-treated plants (Fig. 2c). Under + Fe treatment, NaHS did not significantly affect the FCR activity during the whole experiment period except for $3 \mathrm{~d}$ (Fig. 2d). Apoplastic Fe is one of the major Fe pools in plants. The amount of apoplastic Fe in the root was reduced by 11.1 and $19.8 \%$ at $3 \mathrm{~d}$ and $9 \mathrm{~d}$ in the NaHS-treated plants compared with the $-\mathrm{Fe}$ treatment alone, respectively (Fig. 2e). Under + Fe conditions, NaHS did not significantly affect the apoplastic Fe content in the root throughout the experimental period except at $12 \mathrm{~d}$ (Fig. 2f).

\section{Effect of NaHS on endogenous $\mathrm{H}_{2} \mathrm{~S}, \mathrm{GSH}$, and NPTs content in iron-deficient Glycine max plants}

A high accumulation of endogenous $\mathrm{H}_{2} \mathrm{~S}$ in soybean seedlings leaves and roots caused by exogenous applied $\mathrm{NaHS}$ was observed under the $-\mathrm{Fe}$ and $+\mathrm{Fe}$ conditions (Table 2). Moreover, the NPT content in leaves and roots was increased by exogenous application of NaHS under the $-\mathrm{Fe}$ and $+\mathrm{Fe}$ conditions (Table 2). Additionally, reduced GSH contents in leaves and root were increased 5.3 -fold and $14 \%$ by NaHS under -Fe conditions, respectively. Similarly, under +Fe conditions, the GSH content in leaves and roots was enhanced by NaHS in soybean seedlings (Table 2).

\section{Transcriptome analysis of the effect of NaHS on the expression of different genes in Glycine max plants in response to iron deficiency}

We constructed RNA-Seq libraries for 12 samples (3 replicates per treatment). These RNA libraries were 
A

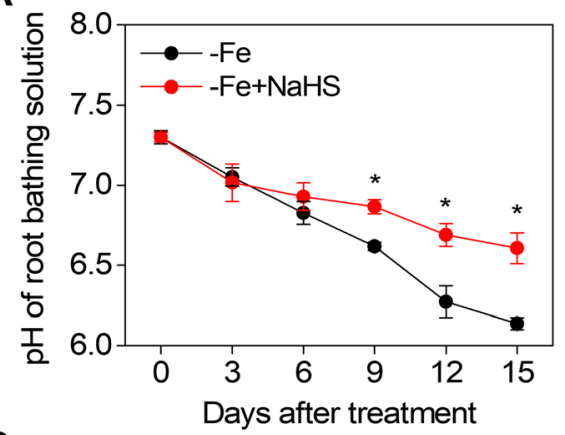

C
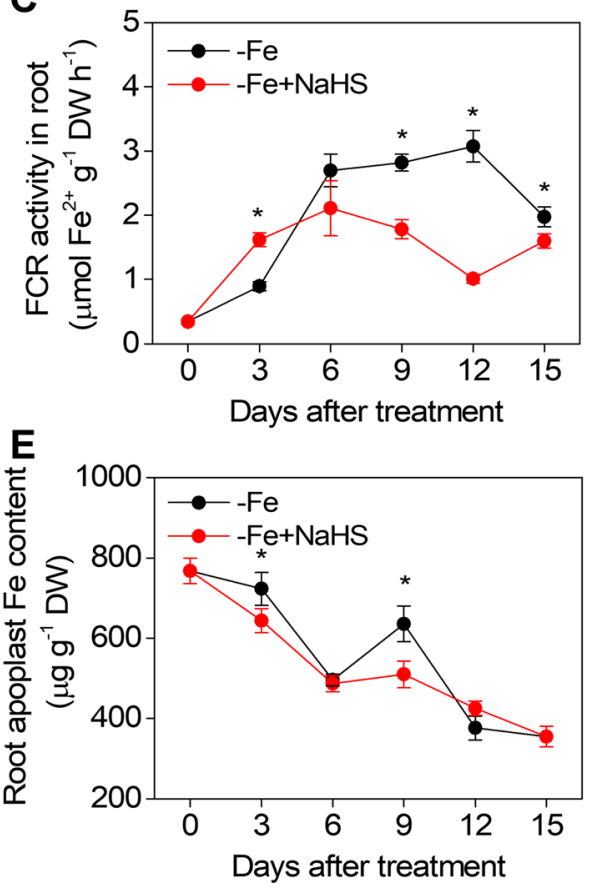

B
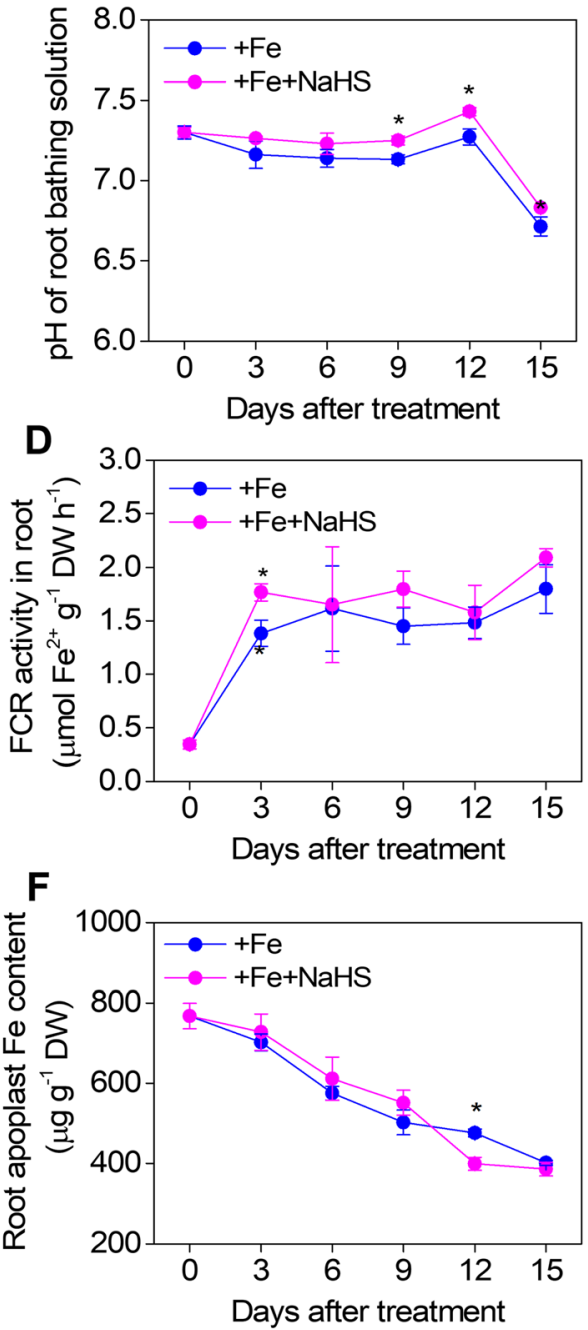

Fig. 2 Effect of NaHS on the pH of the root bathing solution ( $\mathbf{a}$ and $\mathbf{b}$ ), ferric-chelate reductase (FCR) activity (c and $\mathbf{d}$ ), and root apoplast Fe content (e and $\mathbf{f}$ ) of iron-deficient Glycine max plants. The 3-w-old G. max seedlings were treated with the nutrition solution containing $1 \mu \mathrm{M}$ $\mathrm{Fe}(\mathrm{III})$-EDTA or $50 \mu \mathrm{M}$ Fe(III)-EDTA with or without $100 \mu \mathrm{M} \mathrm{NaHS}$ for $15 \mathrm{~d}$. A and B show the pH of the root bathing solution of the $-\mathrm{Fe}$ or $+\mathrm{Fe}$ plants, respectively. $C$ and D show ferric-chelate reductase (FCR) activity of the -Fe or + Fe plants, respectively. E and F show the root apoplast Fe content of the $-\mathrm{Fe}$ or + Fe plants, respectively. Error bars represents the mean $\pm \mathrm{SE}$. ${ }^{*}$ indicates a significant difference at $P<0.05$. $-\mathrm{Fe}$, $1 \mu \mathrm{M}$ Fe; $-\mathrm{Fe}+\mathrm{NaHS}$, seedlings treated with $100 \mu \mathrm{M} \mathrm{NaHS}$ and $1 \mu \mathrm{M} \mathrm{Fe}$ +Fe, $50 \mu \mathrm{M} \mathrm{Fe}$; $+\mathrm{Fe}+\mathrm{NaHS}$, seedlings treated with $100 \mu \mathrm{M} \mathrm{NaHS}$ and $50 \mu \mathrm{M}$ Fe

Table 2 Effect of NaHS on endogenous hydrogen sulfide $\left(\mathrm{H}_{2} \mathrm{~S}\right)$, non-protein thiols (NPTs), and glutathione (GSH) content in leaves and roots of iron-deficient Glycine max plants. The 3-w-old Glycine max seedlings were treated with the nutrition solution containing $1 \mu \mathrm{M}$ Fe(III)-EDTA or $50 \mu \mathrm{M}$ Fe(III)-EDTA with or without $100 \mu \mathrm{M}$ NaHS for 15 days. Error bars represents the mean \pm SE. Different letters indicate significant differences with $P<0.05$. $-\mathrm{Fe}, 1 \mu \mathrm{M} \mathrm{Fe} ;-\mathrm{Fe}+\mathrm{NaHS}$, seedlings treated with $100 \mu \mathrm{M} \mathrm{NaHS}$ and $1 \mu \mathrm{M}$ Fe; $+\mathrm{Fe}, 50 \mu \mathrm{M} \mathrm{Fe}$; +Fe + NaHS, seedlings treated with $100 \mu \mathrm{M} \mathrm{NaHS}$ and $50 \mu \mathrm{M}$ Fe

\begin{tabular}{|c|c|c|c|c|c|c|}
\hline \multirow[t]{2}{*}{ Treatment } & \multicolumn{2}{|c|}{ Endogenous $\mathrm{H}_{2} \mathrm{~S}$ content $\left(\mu \mathrm{mol} \mathrm{g}{ }^{-1} \mathrm{FW}\right)$} & \multicolumn{2}{|c|}{ NPTs $\left(\mu \mathrm{mol} \mathrm{g}{ }^{-1} \mathrm{FW}\right)$} & \multicolumn{2}{|c|}{ GSH (nmol g $\left.{ }^{-1} \mathrm{FW}\right)$} \\
\hline & Leaf & Root & Leaf & Root & Leaf & Root \\
\hline$-\mathrm{Fe}$ & $0.046 \pm 0.013 b$ & $0.013 \pm 0.004 C$ & $7.56 \pm 0.20 b$ & $3.74 \pm 0.10 \mathrm{~B}$ & $28.56 \pm 5.71 \mathrm{c}$ & $164.4 \pm 9.71 \mathrm{~B}$ \\
\hline$-\mathrm{Fe}+\mathrm{NaHS}$ & $0.123 \pm 0.014 a$ & $0.075 \pm 0.010 \mathrm{~A}$ & $8.95 \pm 0.29 \mathrm{a}$ & $4.88 \pm 0.44 \mathrm{~A}$ & $149.5 \pm 15.6 b$ & $187.1 \pm 6.62 \mathrm{~A}$ \\
\hline$+\mathrm{Fe}$ & $0.056 \pm 0.007 b$ & $0.029 \pm 0.002 \mathrm{~B}$ & $7.96 \pm 0.64 \mathrm{ab}$ & $4.05 \pm 0.27 \mathrm{~B}$ & $162.3 \pm 10.7 b$ & $166.2 \pm 10.8 B$ \\
\hline$+\mathrm{Fe}+\mathrm{NaHS}$ & $0.119 \pm 0.010 \mathrm{a}$ & $0.098 \pm 0.017 \mathrm{~A}$ & $8.37 \pm 0.25 \mathrm{a}$ & $5.28 \pm 0.26 \mathrm{~A}$ & $240.2 \pm 15.7 \mathrm{a}$ & $182.4 \pm 5.34 \mathrm{~A}$ \\
\hline
\end{tabular}


sequenced using an Illumina Hiseq 4000 platform, and a total of 50,315,998 (-Fe), 56,902,806 (-Fe + NaHS), 60, $885,868(+\mathrm{Fe})$, and 50,140,356 (+Fe $+\mathrm{NaHS})$ sequence reads were generated (Table S1). The replication of the data in every treatment was quite high, and the $\mathrm{R}^{2}$ was approximately 0.9 (Fig. S6). An overview of the sequencing and assembly was outlined in Table S1 and Table S2. We pooled the short reads and aligned them against the soybean genome and found that approximately $87.31-89.19 \%$ of the reads mapped to genes (Table S1).

Based on the deep sequencing of the 12 libraries in the present study, 54,718 genes were detected from soybean roots in the Fe deficiency treatment, which covered from at least $82 \%$ of the reference genes in soybean. Moreover, under -Fe conditions, the application of NaHS affected 5606 DEGs, of which 2368 were up-regulated genes and 3238 were down-regulated genes (Fig. S7A). Similarly, under $+\mathrm{Fe}$ conditions, NaHS regulated 6121 DEGs, of which 2721 were up-regulated genes and 3400 were down-regulated genes (Fig. S7B). Among these DEGs, 309 and 980 DEGs in soybean roots were coupregulated and -downregulated by $\mathrm{NaHS}$ under $-\mathrm{Fe}$ and $+\mathrm{Fe}$ conditions, respectively (Fig. 5a). These upregulated and down-regulated DEGs are clustered in Fig. 3c. The detailed information is listed in Table S5-8. Additionally, to understand the function of DEGs, we used a KEGG pathway network to identify their enrichment among different metabolic pathways. Significantly enriched KEGG pathways were identified using a $P$-value based on the hypergeometric distribution. For instance, under -Fe conditions, twenty pathways were significantly enriched by NaHS treatment. This KEGG pathways network analysis showed that "sulphur metabolism", "plant hormone signal transduction", "metabolism", "porphyrin and chlorophyll metabolism", and "cysteine and methionine", among others, were significantly enriched under -Fe conditions (Fig. 3b). Meanwhile, the GO analysis had listed in Fig. S8.

\section{NaHS regulates the expression of iron homeostasis- related genes in iron-deficient Glycine max plants}

The transcriptome data showed that iron homeostasisrelated genes, including $3 H^{+}$-ATPase $(H A)$ genes, 2 bHLHs genes, and 2 ferritins genes ( $f e r)$, were regulated by NaHS under $-\mathrm{Fe}$ and $+\mathrm{Fe}$ conditions (the transcriptome data are presented using clustering in Fig. 4). To further confirm the transcriptome result, the qRT-PCR method was used (the qRT-PCR data are presented using column graphs in Fig. 4). As shown in Fig. 4, the expression levels of $3 \mathrm{GmHAs}$ genes were up-regulated in the NaHS treatment under $-\mathrm{Fe}$ and $+\mathrm{Fe}$ conditions. Moreover, the qRT-PCR results also showed that NaHS significantly promoted the transcript abundances of the GmHA gene under the same conditions. Additionally, the expression abundances of GmFRO2 and GmFRO7 were obviously decreased by NaHS under $-\mathrm{Fe}$ conditions. By contrast, the expression levels of the GmFCR were significantly enhanced by NaHS under the same conditions. Moreover, under $+\mathrm{Fe}$ conditions, NaHS affected the expression abundances of GmFRO7 and GmFCR in the roots of soybean seedlings. In addition, the transcriptome data showed that the expression levels of $2 \mathrm{GmbHLHs}$ were obviously increased by NaHS under $-\mathrm{Fe}$ and $+\mathrm{Fe}$ conditions, and the qRT-PCR analysis further confirmed these results. The expression levels of GmIRT and GmDMT1 were significantly down-regulated by NaHS under $-\mathrm{Fe}$ and $+\mathrm{Fe}$ conditions. Finally, the 2 Gmfers expression levels were not affected by $\mathrm{NaHS}$ under $-\mathrm{Fe}$ conditions, but under $+\mathrm{Fe}$ conditions the expression levels of these two genes were significantly increased compared with the - Fe treatment. Similarly, the qRT-PCR analysis also indicated that Fe and NaHS could obviously increase the expression levels of Gmfer2 and Gmfer4 genes in the roots of soybean seedlings.

\section{NaHS affects the expression of Sulphur metabolism- related genes in iron-deficient Glycine max plants}

Sulphur (S) metabolism-related genes, including GmST, GmATPS, GmAPK, GmAPR, GmSiR, GmSAT, GmOAS$T L, G m C G S, G m C B L$, and GmMetS, are modulated by $\mathrm{NaHS}$ in the roots of soybean under $-\mathrm{Fe}$ and $+\mathrm{Fe}$ conditions using the transcriptome method (Fig. 5a). The expression abundances of 6 GmSTs genes were significantly enhanced by NaHS under -Fe and + Fe conditions in the roots of soybean (Fig. 5a). Similarly, the qRT-PCR results showed that NaHS significantly upregulated the expression of the GmST2.1 in the roots of -Fe plants, but this gene expression level slightly decreased under $+\mathrm{Fe}$ conditions (Fig. 5b). The expression levels of 2 GmATPS genes showed obvious increases in the NaHS-treated plants compared with the plants that were not treated with NaHS in the presence or absence of $\mathrm{Fe}$ in the roots of soybean seedlings; the qRT-PCR analysis further confirmed these results (Fig. 5). Additionally, NaHS obviously increased the expression levels of 3 GmAPRs genes in the roots of -Fe plants. However, under $+\mathrm{Fe}$ conditions, the expression levels of these three genes were obviously decreased by NaHS. Similarly, the expression of the $2 \mathrm{GmSiR}$ and GmAPK genes were up-regulated by $\mathrm{NaHS}$ under $-\mathrm{Fe}$ and $+\mathrm{Fe}$ conditions. The expression levels of five GmSAT genes were changed by NaHS in the roots of $-\mathrm{Fe}$ and + Fe plants, and the qRT-PCR data indicated that the GmSAT1 gene expression level was up-regulated by NaHS under -Fe conditions, but was not affected in the + Fe plants (Fig. 5). Moreover, the expression abundances of $3 \mathrm{GmOAS}-T L$ genes were enhanced by the NaHS treatment in the $-\mathrm{Fe}$ plants, but these three genes were significantly down- 


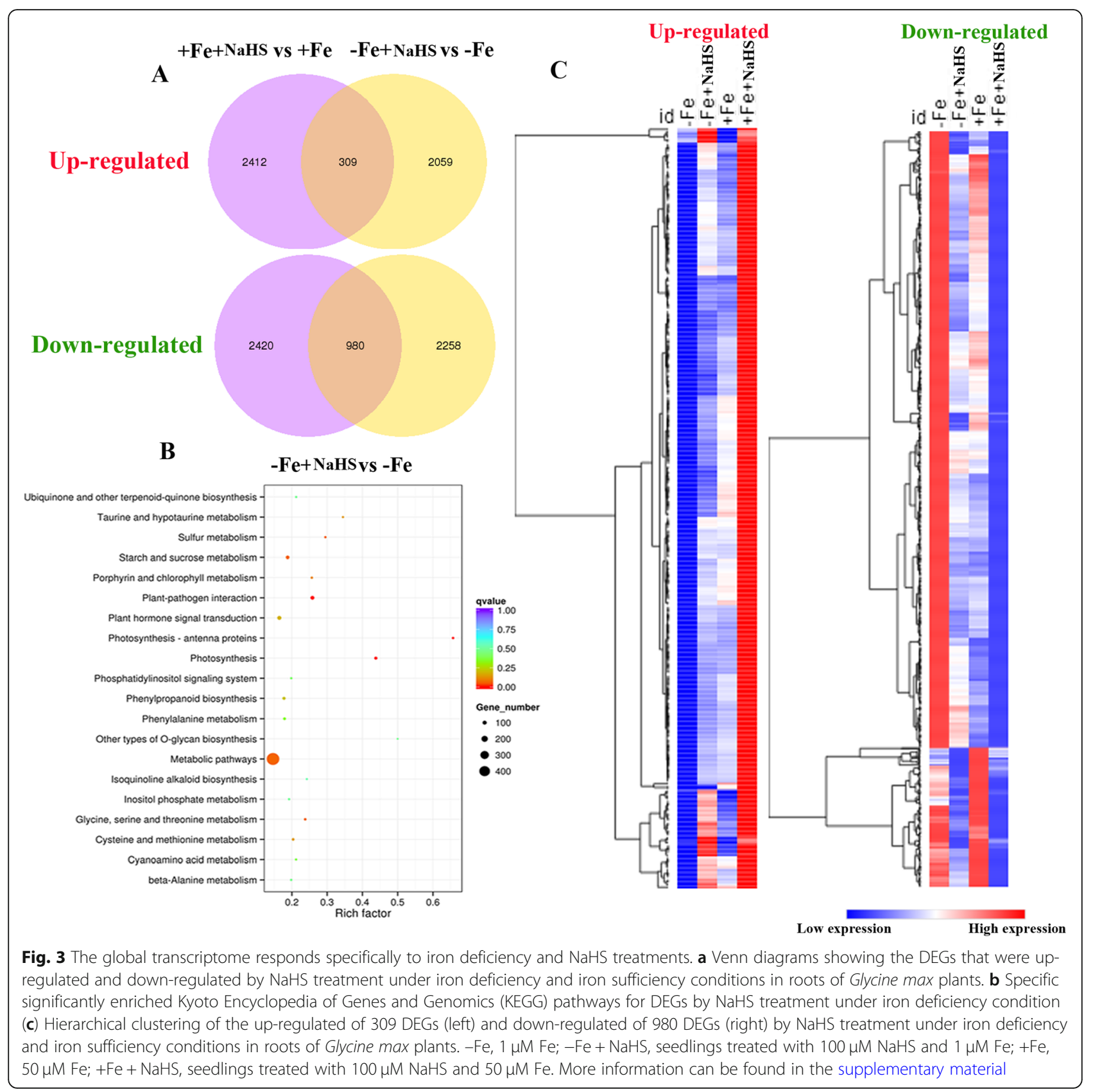

regulated under $+\mathrm{Fe}$ conditions. The gene expression levels of $G m C y S$ were up-regulated by NaHS under $-\mathrm{Fe}$ and + Fe conditions. Moreover, the expression abundances of GmCGS and $G m C B L$ were obviously induced by NaHS in the roots of soybean seedlings, and the qRT-PCR data further confirmed this result. Interestingly, NaHS treatment slightly inhibited the expression level of the GmDES gene under -Fe conditions, but this gene expression level was significantly up-regulated by NaHS under $+\mathrm{Fe}$ conditions. Finally, the expression abundances of $5 \mathrm{GmMetSs}$ genes were affected to different degrees by NaHS under $-\mathrm{Fe}$ and $+\mathrm{Fe}$ conditions, and the qRT-PCR data indicated that NaHS treatment could up-regulate their gene expression abundances in the roots of soybean seedlings. In addition, we also analyzed other thioor stress-related genes, including GmSAM-Mtase, GmThr, GmGR, GmGST, and GmGDH1, in the roots of -Fe plants using qRT-PCR. The expression levels of GmThr and GmGST were significantly down-regulated by $\mathrm{NaHS}$ under $-\mathrm{Fe}$ conditions in the roots of soybean seedlings, but under the same conditions NaHS treatment did affect the expression abundances of the GmSAM-Mtase and GmGR genes. However, the expression level of the $G m G D H 1$ gene was significantly up-regulated by NaHS under -Fe conditions, while the opposite result was observed under $+\mathrm{Fe}$ conditions. 


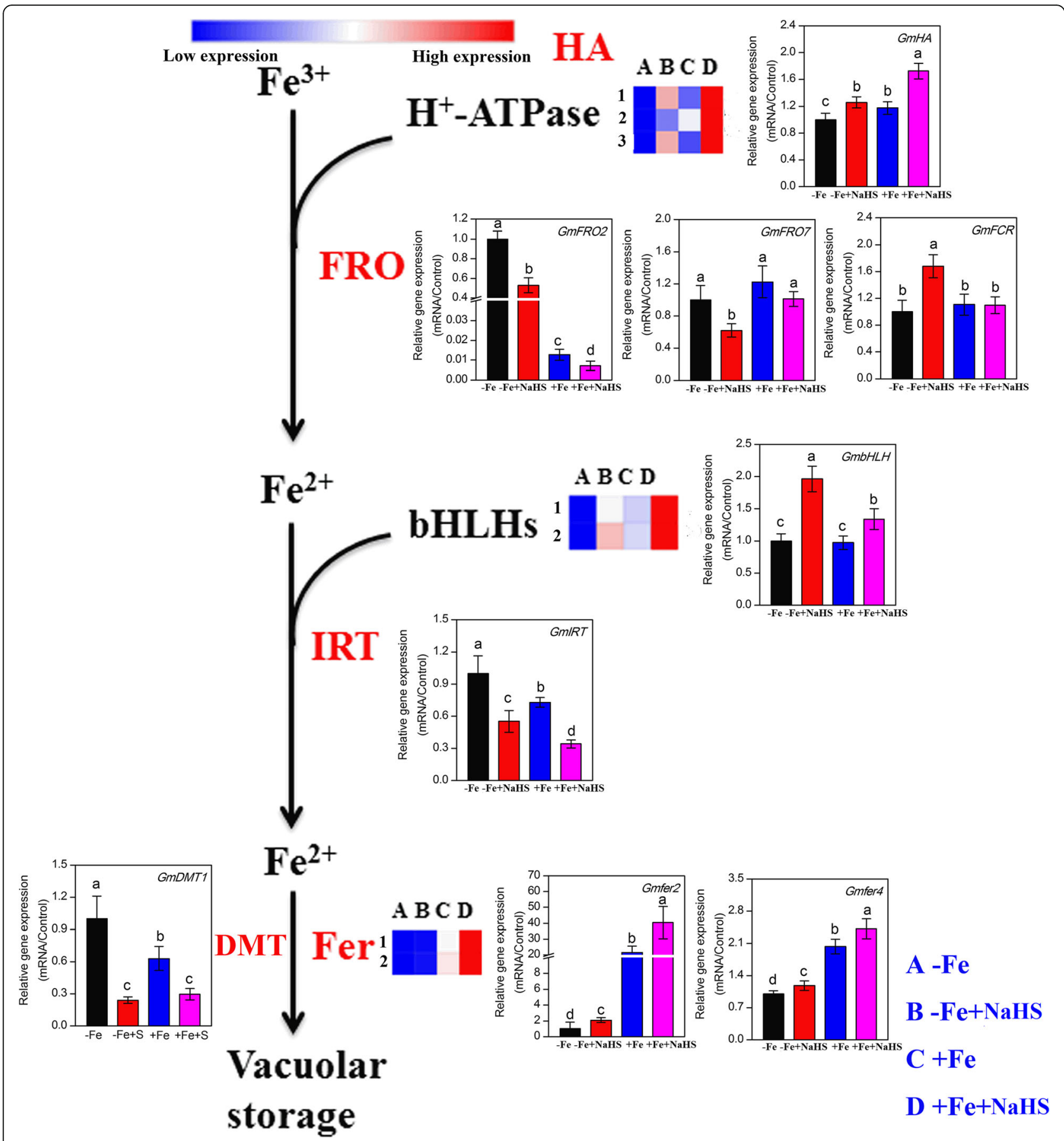

Fig. 4 Genes in the iron assimilation pathway were regulated by NaHS treatment under iron deficiency and iron sufficiency conditions in roots of Glycine max plants. Transcript levels of genes are listed in the figure, and the detailed DEGs are listed in supplementary Table S5. The data of columns indicated the gene expression of iron assimilation using RT-PCR. The relative mRNA levels of each gene were normalized to the mRNA of GMEIFIB and Gmactin. Data are presented as the mean \pm SE $(n=3)$. Columns labelled with different letters indicate significant differences at $P<0.05$. Abbreviations of gene names are provided in supplementary Table S3. A: -Fe, $1 \mu \mathrm{M} F$; B: $-\mathrm{Fe}+\mathrm{NaHS}$, seedlings treated with $100 \mu \mathrm{M}$ $\mathrm{NaHS}$ and $1 \mu \mathrm{M} \mathrm{Fe} ; \mathrm{C}:+\mathrm{Fe}, 50 \mu \mathrm{M} \mathrm{Fe} ; \mathrm{D}:+\mathrm{Fe}+\mathrm{NaHS}$, seedlings treated with $100 \mu \mathrm{M} \mathrm{NaHS}$ and $50 \mu \mathrm{M} \mathrm{Fe}$

Plant hormones play an important role in NaHS-induced adaption to iron deficiency in Glycine max plants As shown in Fig. 6, in the auxin pathway, the expression levels of 1 GmTIR1 and 3 GmARFs genes were significantly increased by NaHS in the roots of soybean seedling grown under $-\mathrm{Fe}$ and $+\mathrm{Fe}$ conditions. By contrast, the expression abundances of 12 GmAUX/IAAs genes were all down-regulated by NaHS under -Fe 


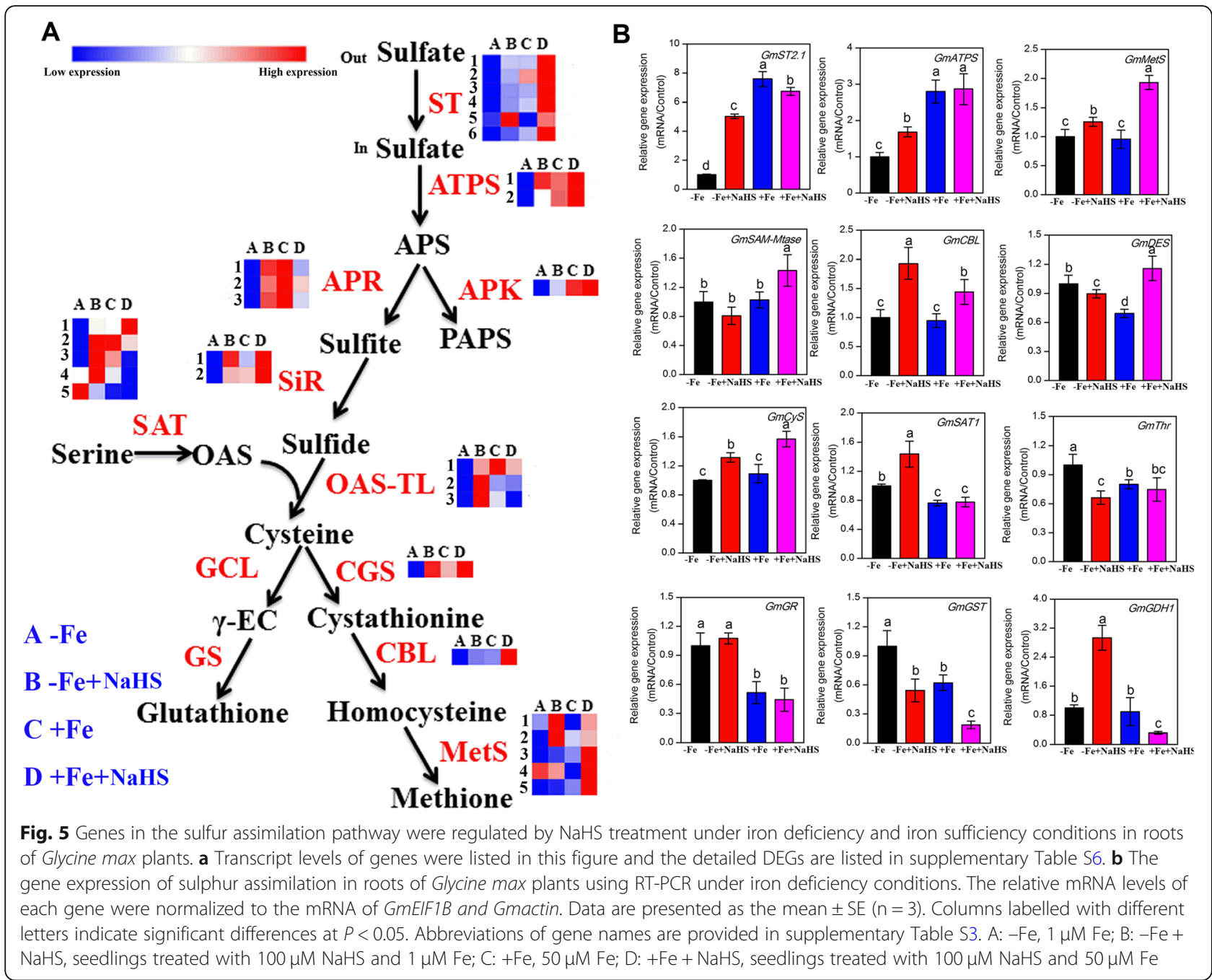

and $+\mathrm{Fe}$ conditions. Similarly, most of the GmGH3 and GmSAUR expression levels were obviously decreased by $\mathrm{NaHS}$ treatment under -Fe conditions. Moreover, in the cytokinine (CTK) pathway, NaHS treatment significantly down-regulated the expression levels of the GmCRE1, $G m A H P, G m A-A R R$, and $2 G m B-A R R$ genes under $-\mathrm{Fe}$ conditions, but the expression levels of 5 other $G \mathrm{mB}$ $A R R$ genes were up-regulated in the roots of soybean seedlings. By contrast, in the gibberellin (GA) pathway, the expression of GmGID1 and GmDELLA were significantly up-regulated by NaHS treatment under $-\mathrm{Fe}$ conditions, but GmTF was obviously down-regulated under the same conditions. Moreover, NaHS treatment significantly decreased the gene expression levels of GmPP2C, GmSnRK2, and GmABF in the abscisic acid (ABA) pathway under $-\mathrm{Fe}$ conditions. Nevertheless, the $2 \mathrm{GmPYT/}$ $P Y L$ genes were up-regulated in the roots of soybean seedlings. In the ethylene (ETH) pathway, the expression levels of all genes, including GmETR, GmCTR1, GmEIN2, GmEBF1/2, GmEIN3, and GmERF1/2, were significantly down-regulated by NaHS in the roots of soybean seedlings under - Fe conditions. Additionally, in the brassinosteroid (BR) pathway, the expression levels of the GmBAK1, GmBKI1, GmTCH4, and GmCYCD3 genes were obviously decreased by $\mathrm{NaHS}$ in the roots of $-\mathrm{Fe}$ plants. However, the expression abundances of GmBRI1 and GmBSK were enhanced under the same conditions. Moreover, under -Fe conditions, NaHS treatment significantly down-regulated all genes involved in the jasmonic acid (JA) pathway in the roots of soybean seedlings, which contains the genes GmJAR1, GmCOI1, GmJAZ, and GmMYC2. Finally, the expression abundances of GmTGA and GmPR-1 were significantly down-regulated by NaHS treatment under $-\mathrm{Fe}$ conditions.

The content of plant hormones was affected by NaHS under -Fe conditions (Fig. 7). For instance, NaHS treatment significantly decreased the ABA and ZA (zeatin, $\mathrm{ZA}$, a natural cytokinins in plants) contents in the leaves of $-\mathrm{Fe}$ plants, but this difference was not obvious in the 


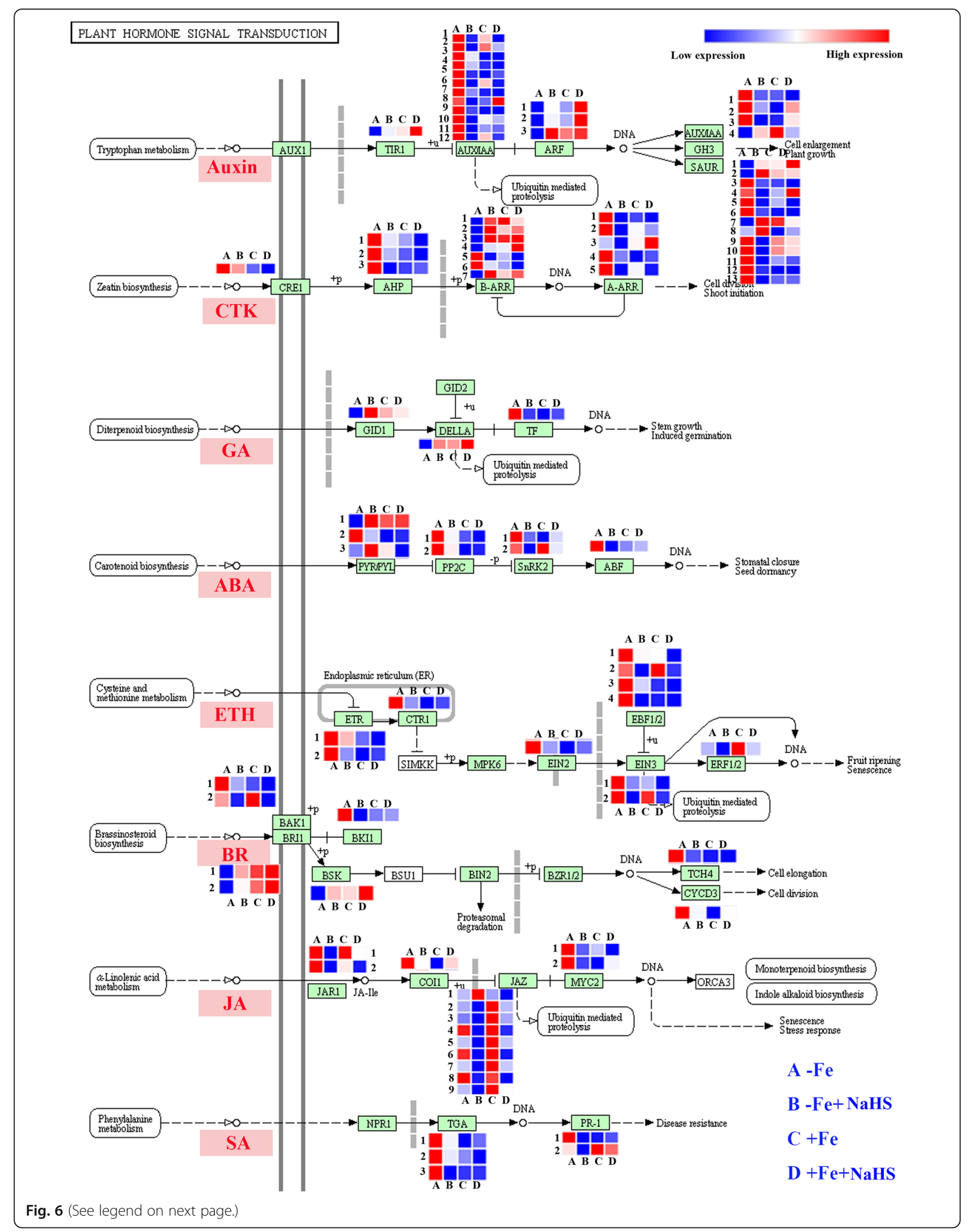


(See figure on previous page.)

Fig. 6 Genes in the plant hormones pathway were regulated by NaHS treatment under iron deficiency and iron sufficiency conditions in roots of Glycine max plants. Transcript levels of genes are listed in the figure and the detailed DEGs are listed in supplementary Table S7. CTK, cytokinin; GA, gibberellin; ABA, abscisic acid; ETH, ethylene; BR, brassinosteroid; JA, jasmonic acid; SA, salicylic acid; A: -Fe, $1 \mu \mathrm{M}$ Fe; B: -Fe + NaHS, seedlings treated with $100 \mu \mathrm{M}$ NaHS and $1 \mu \mathrm{M} \mathrm{Fe}$; $:$ +Fe, $50 \mu \mathrm{M}$ Fe; D: +Fe + NaHS, seedlings treated with $100 \mu \mathrm{M} \mathrm{NaHS}$ and $50 \mu \mathrm{M}$ Fe

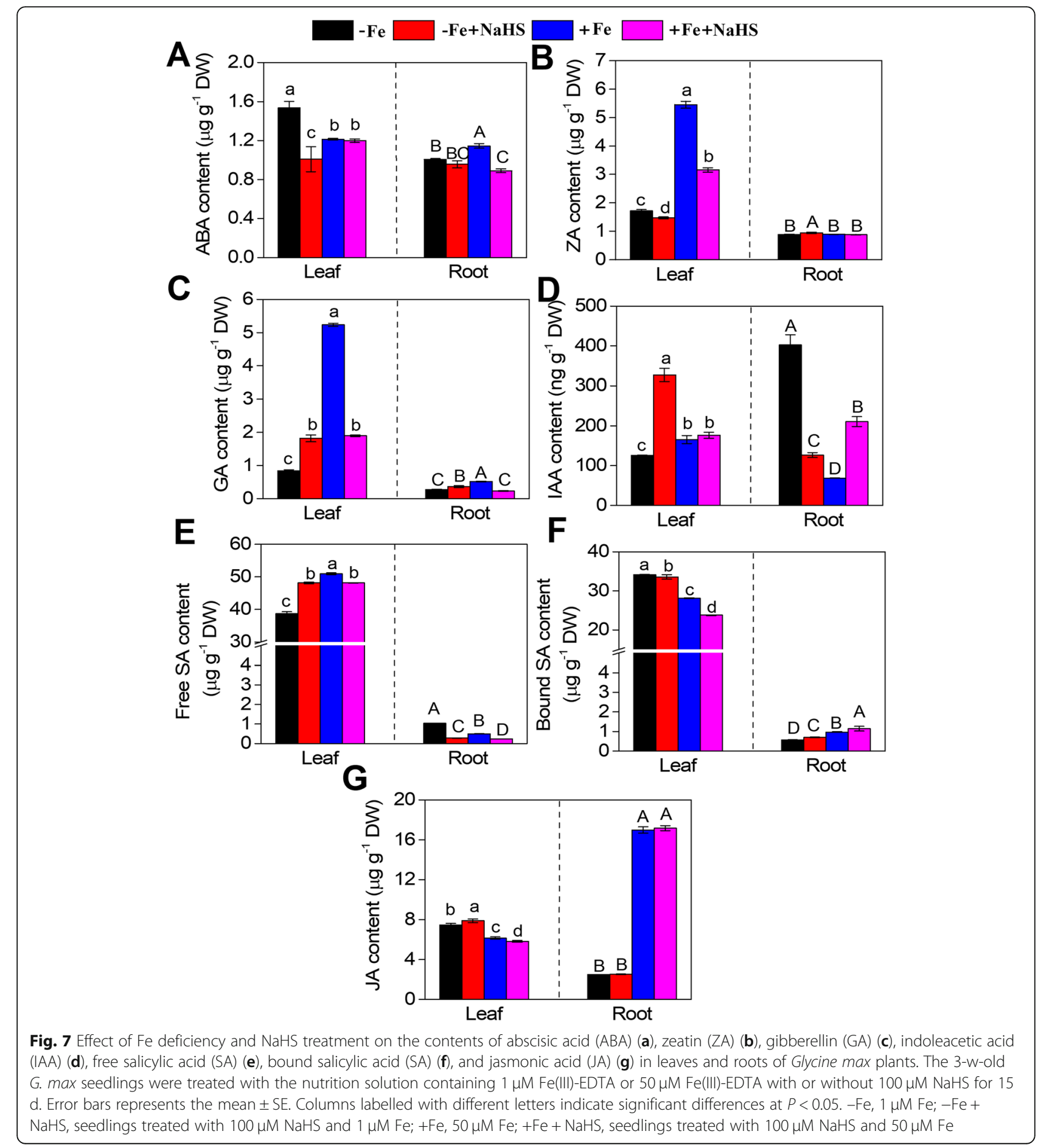


roots (Fig. 7a, b). In contrast, the GA contents in the leaves and roots of soybean seedlings were increased by NaHS under -Fe conditions, but the GA content showed an obvious decrease under + Fe conditions (Fig. 7c). Moreover, the IAA content in leaves of soybean seedlings was obviously increased by NaHS under -Fe conditions, but NaHS treatment decreased the IAA content in the roots under the same conditions (Fig. 7d). NaHS treatment promoted the free SA synthesis in the leaves but decreased the free SA content in the roots under -Fe conditions (Fig. 7e). In contrast, the bound SA content in the leaves showed a slight decrease but increased in roots under -Fe and + Fe conditions (Fig. 7f). The JA content in the leaves was slightly increased by NaHS under -Fe conditions, but the JA content was decreased under + Fe conditions (Fig. 7g). In addition, NaHS did not affect the JA content in roots under - Fe and + Fe conditions (Fig. 7g).

\section{NaHS regulates the expression of organic acid} metabolism-related genes and the organic acid contents in iron-deficient Glycine max plants

The expression abundances of organic acid metabolismrelated genes were modulated by NaHS in the roots of -Fe plants (Fig. 8a). For instance, the expression levels of 2 GmCS genes were affected by NaHS under $-\mathrm{Fe}$ and $+\mathrm{Fe}$ conditions, and the qRT-PCR data showed that NaHS upregulated the gene expression level of GmCS under -Fe conditions, but no significant effect was found under $+\mathrm{Fe}$ conditions. Additionally, the expression levels of the GmACO, GmOGH and GmSDH genes were obviously upregulated by NaHS under $-\mathrm{Fe}$ and $+\mathrm{Fe}$ conditions. Similarly, NaHS treatment also significantly increased the gene expression levels of GmMS under -Fe and + Fe conditions in the roots of soybean seedlings. Moreover, the expression abundances of $2 \mathrm{GmMDHs}$ genes were changed by NaHS, and the qRT-PCR data indicated that NaHS slightly downregulated the expression levels of these genes under $-\mathrm{Fe}$ conditions, but the expression levels of these genes were significantly up-regulated under $+\mathrm{Fe}$ conditions. In addition, we also analyzed the citric acid and malic acid contents in the leaves and roots of soybean seedlings under $-\mathrm{Fe}$ and $+\mathrm{Fe}$ conditions. As shown in Fig. 8b, under $-\mathrm{Fe}$ and $+\mathrm{Fe}$ conditions, the citric acid contents in leaves were significantly increased by NaHS, but in the roots, NaHS treatment slightly decreased the citric acid contents under -Fe conditions. However, the malic acid content obviously decreased in response to NaHS treatment in the leaves of Fe plants.

\section{Discussion}

$\mathrm{H}_{2} \mathrm{~S}$ regulates chlorophyll biosynthesis and photosynthesis in iron-deficient plants

Soybean (Glycine max L.) is an agronomic crop belonging to the legume family and is the plant species with

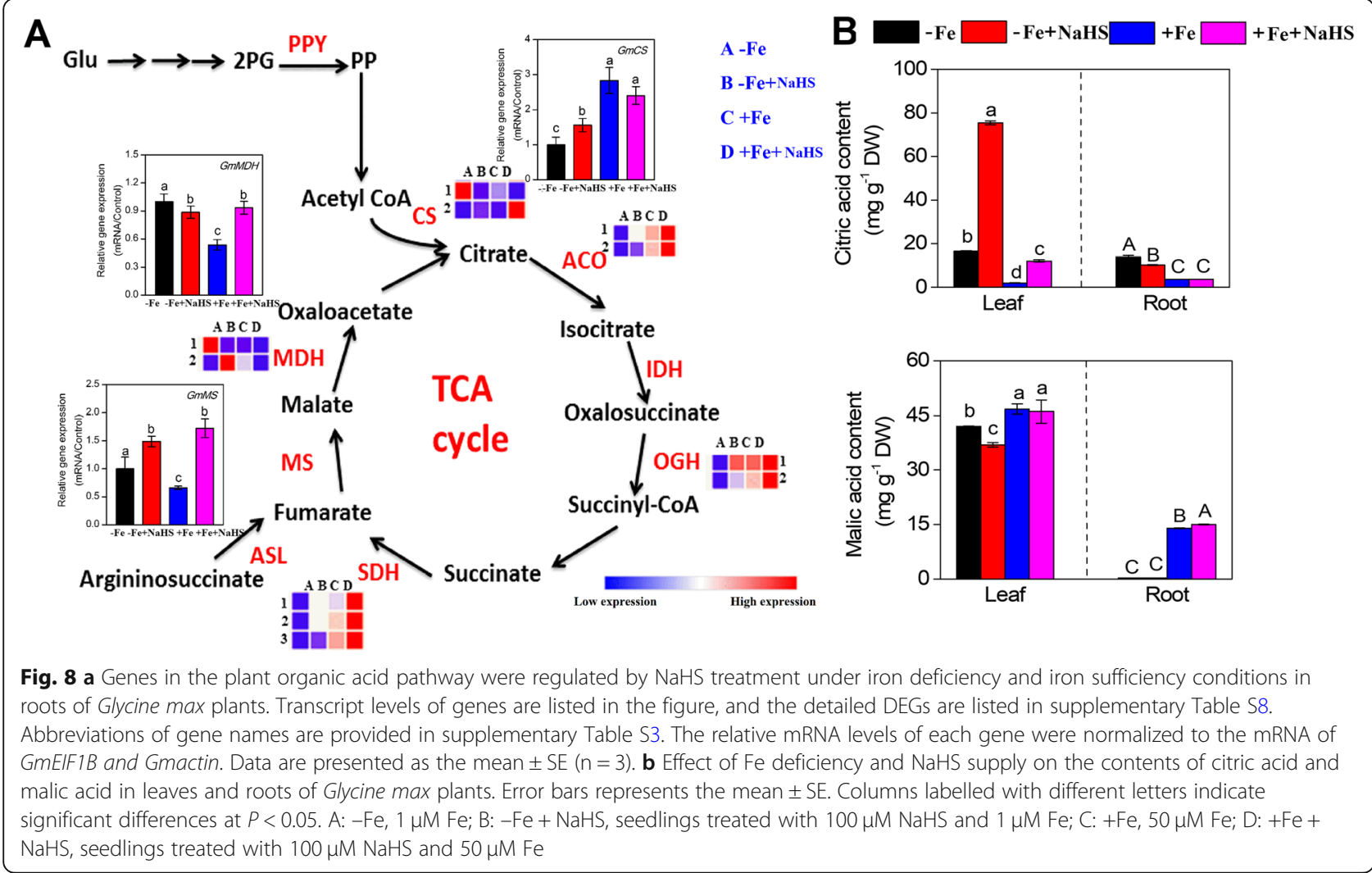


the second-highest iron (Fe) content [42]. Soybean is especially very sensitive to Fe deficiency chlorosis [42]. Exposed to $\mathrm{Fe}$ deficiency, chlorophyll biosynthesis and photosynthesis are significantly inhibited, and negatively affecting soybean yields [42, 43]. Fe deficiency leads to chlorosis due to decreased chlorophyll biosynthesis, which in turn causes the yellowing of younger leaves and reductions in leaf area and shoot and root dry weight $[44,45]$. In addition, Fe is vital for the establishment and function of symbiotic root nodules of legumes, which are involved in nitrogen fixation [46, 47]. In low Fe conditions, the legume plants may need to develop mechanisms involved in the acquisition and utilization of $\mathrm{Fe}$ to protect its symbiotic organs against the low availability of $\mathrm{Fe}$ [48]. Therefore, soybean can be used as a new model plant in understanding the Fe deficiency tolerance mechanisms. In the present study, our results showed that Fe deficiency could significantly inhibit the nodule number and decrease the nodule dry weight in soybean plants compared with Fe sufficiency, but the application of NaHS could obviously alleviate the $\mathrm{Fe}$ deficiency-induced decrease in nodule number and dry weight in soybean plants (Fig. S2A and B). Moreover, under $+\mathrm{Fe}$ conditions, NaHS could also promote the nodule number and nodule weight in soybean plants (Fig. S2A and B). These results are consistent with previous studies showing that low Fe conditions can inhibit the nodule number in legumes [46, 47]. Moreover, Fe deficiency disrupts the chloroplast ultrastructure and degrades chloroplast protein components [7, 40], further inhibiting photosynthesis and photosystem II in plants [7]. In the present study, soybean seedlings experiencing Fe deficiency for $15 \mathrm{~d}$ displayed severe chlorotic characteristics with interveinal yellowing and a low chlorophyll concentration (Fig. 1 and Table 1). Similarly, a typical phenotype of chlorosis in Arabidopsis, tomato, and maize seedlings grown in a Fe-deficient solution has been reported [10, 11, 20]. Interestingly, NaHS significantly increased the chlorophyll content in Fe-deficient soybean seedlings, which is consistent with the results of our previous study showing that $\mathrm{H}_{2} \mathrm{~S}$ promotes chlorophyll synthesis under Fe deficiency in maize seedlings, a strategy II plant [10]. Additionally, Fe deficiency causes a decrease in chlorophyll, leading to a reduction in photosynthesis and photosystem II in plants [49]. Moreover, chlorotic leaves caused by Fe deficiency exhibit lower stomatal apertures and lower photosynthetic rates and an eventual reduction in WUE [50]. Furthermore, Fe deficiency affects photosynthetic electron transport, with concomitant reductions in carbon assimilation and biomass [51]. In the present study, the light-response curves indicated that NaHS promoted photosynthesis and that this process was closely related to $\mathrm{Fe}$ acquisition in $\mathrm{Fe}$ deficient plants (Fig. S3A). Additionally, water use efficiency (WUE) was also obviously enhanced by $\mathrm{NaHS}$ (Fig. S3D). The same results were obtained in our previous study on maize seedlings grown in an Fe-deficient solution [10]. However, NaHS had different response to photosynthesis and photosystem II between $-\mathrm{Fe}$ and + Fe conditions in soybean seedlings. For instance, under -Fe conditions, the application of NaHS could promote photosynthesis and chlorophyll fluorescence parameters, including PSII, ETR, Fv/Fm, and Fv'/Fm`, but under + Fe conditions, this response was not obvious and even showed a decrease (Fig. S3 and S4). The possible explanation is that under $-\mathrm{Fe}$ conditions, $\mathrm{H}_{2} \mathrm{~S}$ plays a positive role in protecting plants against the damage caused by Fe deficiency, but under $+\mathrm{Fe}$ conditions, plant can grow and develop normally and do not need other signalling molecules, such as $\mathrm{H}_{2} \mathrm{~S}$. The same phenomenon is also found in maize seedlings under Fe-deficient conditions [10]. Similarly, ABA or putrescine have different responses to physiological indexes between $-\mathrm{Fe}$ and $+\mathrm{Fe}$ conditions in plants $[20,52]$. Taken together, the above results indicated that $\mathrm{H}_{2} \mathrm{~S}$-improved photosynthesis and photosystem II were possibly dependent on Fe availability in soybean seedlings.

\section{$\mathrm{H}_{2} \mathrm{~S}$ promotes iron accumulation by changing of $\mathrm{FCR}$ enzyme activities and iron homeostasis-related genes expression in iron-deficient plants}

$\mathrm{Fe}$ uptake and translocation are regulated by $\mathrm{Fe}$ homeostasis-related genes in plants [53], and Fe deficiencyinduced chlorosis results in restricted Fe mobility from old to young leaves. In the present study, NaHS significantly improved Fe accumulation in soybean seedling tissues under Fe conditions (Table 1). Moreover, the high Fe concentration did not affect the deficiencies of other micronutrients $(\mathrm{Mn}$, $\mathrm{Cu}$ and $\mathrm{Zn}$ ) (Fig. S5). These results are in agreement with those from previous studies showing that $\mathrm{NO}$ and ABA regulate $\mathrm{Fe}$ accumulation and transport in tomato and Arabidopsis $[11,20]$. Additionally, three consecutive activities in epidermal cell membranes are involved in the Fe uptake from the root of soybean plants [42]. The acidification of rhizosphere by the protons transported through a membrane-bound $\mathrm{H}^{+}$-ATPase (AHA) in the epidermal cells is the first activity. Then, the second activity is that $\mathrm{Fe}^{3+}$ is reduced to soluble $\mathrm{Fe}^{2+}$ by FCR. Finally, the iron-regulated transporter1 (IRT1) transports $\mathrm{Fe}^{2+}$ ions into the epidermal cells [8]. In the present study, we found that Fe deficiencyinduced FCR activity in the roots of soybean seedlings during the treatments period, but NaHS inhibited the increase in $\mathrm{Fe}$ deficiency-induced root FCR activity (Fig. 2c), suggesting that $\mathrm{H}_{2} \mathrm{~S}$ plays an important role in regulating the response of $\mathrm{Fe}$ deficiency in plants. Similarly, previous study found that FCR activity was related to the Fe concentration in soybean plants [54]. Rhizosphere acidification-mediated by proton ATPase is another important Fe-deficient response for strategy I 
plants, and this response has been associated with activity of a plasmalemmalocalized $\mathrm{H}^{+}$-ATPase. Interestingly, $\mathrm{NaHS}$ significantly inhibited the Fe deficiency-induced decrease in the $\mathrm{pH}$ of the root bathing solution. Additionally, recent evidence has shown that root apoplastic Fe can be partially remobilized under Fe deficiency [20, 55]. Here, the amount of apoplastic Fe in roots obviously decreased under Fe deficiency conditions, and this decrease was more pronounced in the presence of NaHS (Fig. 2e), indicating that $\mathrm{H}_{2} \mathrm{~S}$ promotes the reutilization of root apoplastic $\mathrm{Fe}$ in soybean seedlings. The probable mechanism for this process may be as follows: $\mathrm{H}_{2} \mathrm{~S}$ react with Fe fixed in the apoplast, making the $\mathrm{Fe}$ available for absorption by root cells for translocation to the shoot.

We used the transcriptome and RT-PCR methods to analyze the $\mathrm{Fe}$ homeostasis-related gene expression abundances, which allowed a better understanding of $\mathrm{Fe}$ deficiency-induced chlorosis and the role of $\mathrm{H}_{2} \mathrm{~S}$ in $\mathrm{Fe}$ acquisition and photosynthesis. Our results showed that NaHS significantly stimulated the expression levels of GmHA genes under Fe deficiency conditions, and these results are consistent with the findings of previous studies indicating that $\mathrm{NO}$ and other signalling molecules can regulate the Fe-deficient response by affecting proton ATPase $(A H A)$ gene expression [52, 56, 57]. In addition, previous studies have shown that the upregulated expression of $F C R$ and IRT might be expected to increase $\mathrm{Fe}$ acquisition in roots, thus strengthening plant tolerance to Fe deficiency [20, 51, 52]. Our results showed that the expression levels of GmFCR were obviously increased by NaHS under Fe deficiency, but two other genes, such as GmFRO2 and GmFRO7, were significantly down-regulated under the same conditions (Fig. 4). One possible explanation for this phenomenon is that the $\mathrm{H}_{2} \mathrm{~S}$-alleviated Fe deficiency response mainly increases the expression of GmFCR rather than the expression abundances of GmFRO2 and GmFRO7 in soybean. Ferritins act as Fe storage proteins and play a major role in Fe mobilization and distribution under Fe deficiency conditions [15, 58]. Moreover, ferritins are mainly located in chloroplasts and accumulate when sufficient $\mathrm{Fe}$ is available in plants. Here, the expression of Gmfer 2 and Gmfer4 were up-regulated by NaHS (Fig. 4), suggesting that $\mathrm{H}_{2} \mathrm{~S}$ promoted Fe mobilization and distribution under $\mathrm{Fe}$ deficiency conditions by regulating the ferritin abundances in soybean seedlings. Similarly, previous studies have also indicated that NO and glutathione promote the accumulation of both ferritin mRNA and protein in Arabidopsis [58, 59]. Additionally, previous studies have suggested that bHLHs, as transcript modulators, play key roles in maintaining Fe homeostasis in plants. Here, the expression of GmbHLH was increased by NaHS under -Fe and + Fe conditions (Fig. 4), suggesting that $\mathrm{H}_{2} \mathrm{~S}$ promotes the adaptability of soybean seedlings to Fe deficiency by affecting the expression abundances of transcript modulators. Soybean divalent metal transporter 1 (GmDMT1) is a soybean homologue of the NRAMP/DMT1 family of divalent metal ion transporters, and that GmDMT1 plays an important role in nodule iron homeostasis [60]. Similarly, we found that Fe deficiency induced higher expression of GmDMT1, but NaHS inhibited the -Fe-induced increase in expression of this gene in the roots of soybean (Fig. 4). Taken together, these results indicated that $\mathrm{H}_{2} \mathrm{~S}$ is a necessary signalling molecule for the expression of iron homeostasis-related genes and related enzyme activities in soybean seedlings under $-\mathrm{Fe}$ and $+\mathrm{Fe}$ conditions.

\section{$\mathrm{H}_{2} \mathrm{~S}$ can regulate Sulphur-containing metabolites and Sulphur metabolism-related gene expression to cope with iron deficiency in Glycine max plants}

Previous studies have shown that a limited S availability reduces Fe uptake and that Fe deficiency results in the modulation of sulfate uptake and assimilation $[61,62]$. It is noteworthy that $\mathrm{S}$ supply could help plants cope with Fe shortage [61]. For instance, tomato seedlings exhibited a positive correlation between the $\mathrm{S}$ nutritional status of the plant and its capability of coping with $\mathrm{Fe}$ deficiency, which are related to the FCR activity, IRT expression and the expression of genes encoding sulfate transporter (STs) [61]. Additionally, Zuchi et al. [63] showed that in tomato plants exposed to both $\mathrm{S}$ and $\mathrm{Fe}$ starvation, no induction of FCR activity, but $S$ deficiency seems to prevent the development of the typical responses to Fe deficiency, and Fe deficiency significantly up-regulated most of the sulfate transporter genes belonging to groups1, 2, and 4. Previous results showed this interaction between $\mathrm{S}$ and Fe triggers the activation of complex response mechanisms to assumingly maintain plant normal growth and development. However, unlike in previous studies, our study mainly focused on the function of $\mathrm{H}_{2} \mathrm{~S}$ signalling rather than sulfur nutrition in improving the adaptation of soybean seedlings to $\mathrm{Fe}$ deficiency. For instance, under $-\mathrm{Fe}$ and $+\mathrm{Fe}$ conditions, NaHS caused a high accumulation of endogenous $\mathrm{H}_{2} \mathrm{~S}, \mathrm{GSH}$ and NPTs in soybean seedling leaves and roots (Table 2). These results indicated that NaHS not only directly promoted the synthesis of endogenous $\mathrm{H}_{2} \mathrm{~S}$ but also fed into cysteine and GSH synthesis by regulating sulphur metabolism-related gene expression in roots.

The pathway of sulphur assimilation in plants is divided into two reaction sequences: sulphate reduction and cysteine synthesis [64]. Here, we found the most sulphur assimilation-related genes were regulated by $\mathrm{NaHS}$ under $-\mathrm{Fe}$ and + Fe conditions in the roots of soybean seedlings using transcriptome and qRT-PCR analysis (Fig. 5). For instance, NaHS increases the transcript levels of the OASTL gene and decrease DES gene 
expression in maize seedlings [10]. The same phenomenon was found in S. oleracea seedlings [39]. Additionally, the biosynthesis of methionine was significantly improved by NaHS under -Fe conditions by affecting the gene expression levels of GmMetS. Finally, we found that the transcript abundances of other S-containing compounds or enzymes, such as GR, GST, and GDH, were modulated by $\mathrm{H}_{2} \mathrm{~S}$ under $-\mathrm{Fe}$ and $+\mathrm{Fe}$ conditions. Therefore, it was concluded that $\mathrm{H}_{2} \mathrm{~S}$, as a signalling molecule, could cope with $\mathrm{Fe}$ deficiency by increasing sulphurcontaining metabolites and modulating the transcript abundances of sulphur metabolism-related genes in soybean seedlings.

\section{Plant hormones play an important role in $\mathrm{H}_{2} \mathrm{~S}$-alleviated iron deficiency in Glycine max plants}

Plant hormones and signalling molecules are involved in the response to Fe deficiency in strategy I plants by inducing the expression of genes related to Fe acquisition and homeostasis [20, 25]. For instance, in the auxin signalling pathway, GmAUX/IAA, GmGH3 and GmSAUR were down-regulated by NaHS under -Fe conditions, but two other genes, GmTIR1 and GmARF, were significantly upregulated under the same conditions. Moreover, our results showed that NaHS decreased the synthesis of auxin IAA in roots but increased auxin IAA in leaves under $-\mathrm{Fe}$ conditions (Fig. 7d), suggesting that $\mathrm{H}_{2} \mathrm{~S}$ regulated the adaptability of Fe deficiency by affecting auxin levels and auxin-related gene expression abundances in soybean seedlings. Similarly, the AUX1-mediated auxin distribution is required for Fe-deficiency-dependent lateral root elongation [65]. Additionally, previous studies have shown that Fe deficiency leads to an increase in the synthesis of auxin and that a high concentration of auxin also enhances $\mathrm{Fe}$ assimilation-related gene expression [56, 66]. Moreover, our results indicated that $\mathrm{H}_{2} \mathrm{~S}$ signalling was involved in regulating $\mathrm{Fe}$ assimilation by affecting the zeatin (ZA) content, a natural cytokinin (CTK) in plants, and downregulating CTK-related gene expression abundances in soybean seedlings under $-\mathrm{Fe}$ conditions. A previous study has shown that CTK, as a negative regulator of Fe-deficiency responses, significantly inhibits several Fe-related genes, such as IRT1 and FRO1 [21], in accordance with our studies. Under -Fe conditions, NaHS enhanced the adaptability to Fe deficiency by inhibiting the synthesis of CTK and CTK-related gene expression levels in soybean seedlings (Fig. 6 and 7b). Additionally, in the gibberellin (GA) signalling pathway, the gene expression abundances of GmGID1 and GmDELLA were obviously up-regulated by NaHS treatment under $-\mathrm{Fe}$ conditions, but TF showed a slight down-regulation under the same conditions. Moreover, the GA contents in the leaves and roots were increased by $\mathrm{NaHS}$ under $-\mathrm{Fe}$ conditions (Fig. 7c), suggesting that $\mathrm{H}_{2} \mathrm{~S}$ signalling could positively control the GA levels by up- regulating the expression of GmGID1 and GmDELLA in soybean plants under Fe deficiency conditions. Interestingly, exogenously applied GAs induced the expression of several Fe uptake-related genes under Fe-deficient and Fesufficient conditions in Arabidopsis [67]. Furthermore, a previous study has shown that GA signalling controls Fe content by regulating the expression abundances of $D E L L$ As and FIT-related transcription factor genes [68]. Similarly, the gene expression abundances involved in the ABA signalling pathway were decreased by NaHS under -Fe conditions. Moreover, ABA synthesis in leaves and roots was inhibited by $\mathrm{NaHS}$ under -Fe conditions (Fig. 7a), suggesting that $\mathrm{H}_{2} \mathrm{~S}$ may modulate ABA synthesis and the expression abundances of related genes under Fe-deficient conditions. Previous studies have shown that exogenous ABA treatment alleviates the chlorosis caused by Fe deficiency by promoting Fe transport and redistribution between shoots and roots [20]. Moreover, exogenous ABA application obviously enhances $\mathrm{Fe}$ uptake by regulating the expression levels of $\mathrm{CmbHLH1}$ in chrysanthemum, suggesting that $\mathrm{ABA}$ may be positively modulated in the process of Fe absorption [69]. In strategy I plants, the transcriptional regulation of a series of $\mathrm{Fe}$-acquisition genes is controlled by ethylene (ETH) [18, 19, 70]. Moreover, the ethylene response factor AtERF4 negatively regulate the Fe-deficient response in Arabidopsis [70]. Interestingly, our results showed that the transcription regulation of a series of ethylene signalling pathway-related genes was modulated by $\mathrm{H}_{2} \mathrm{~S}$ under $-\mathrm{Fe}$ conditions, suggesting that ethylene together with $\mathrm{H}_{2} \mathrm{~S}$ regulated the Fe-deficient response in soybean seedlings. Additionally, the expression abundances of brassinosteroid (BR) signalling pathway-related genes were influenced by NaHS under -Fe conditions. BRs modulate numerous physiological processes in plants [71]. They play a vital role in regulating the responses to Fe deficiency, and BR biosynthesis-defective mutants display a greater tolerance than wild type, suggesting that BRs act as negative regulators of Fe deficiency responses [72]. Jasmonates (JAs) are involved in regulating Fe deficiency in plants [23, 73]. JAs signalling are activated in the very early stages of the Fedeficient response in rice roots, which is partly regulated by the transcription factor IDEF1 and the ubiquitin ligases OsHRZs [73]. The transcript abundances of many JA signalling-related genes, including OsJAZs, OsCOIs, and OsJARs, are influenced by Fe deficiency [73]. In the present study, we found that these genes, including GmJAR1, GmCOI1, GmJAZ, and GmMYC2, involved in the JA signalling pathway were down-regulated by $\mathrm{NaHS}$ under $-\mathrm{Fe}$ conditions, but the JA content in roots was not affected by NaHS under -Fe conditions (Fig. 7g). In plants, the transcript abundances of $b H L H 38$ and bHLH39 are dramatically induced after the application of salicylic acid (SA), which indicates a close relationship between SA and the up-regulation of the Fe-deficient responses [25, 74]. 
Similarly, our results showed that the transcript levels of GmTGA and GmPR-1 involved in the SA signalling pathway were down-regulated by $\mathrm{NaHS}$ under $-\mathrm{Fe}$ conditions in roots. Moreover, the free SA and bound SA contents were changed by NaHS under -Fe conditions (Fig. 7e and f). Taken together, the Fe deficiency response was regulated by $\mathrm{H}_{2} \mathrm{~S}$ signalling and a series of complex interactions among several different plant hormones by controlling biosynthesis and signal transduction-related gene expression abundances of plant hormones in soybean seedlings.

\section{Organic acid biosynthesis-related gene expression and organic acid contents are regulated by $\mathrm{H}_{2} \mathrm{~S}$ in iron- deficient Glycine max plants}

Citrate has been considered to be the most likely major candidate for Fe transport among carboxylates present in xylem sap [75]. Moreover, increased carboxylates concentrations, including citrate and malate, as well as enhanced expression of TCA cycle-related transcripts in the root tissues of plants, are important in alleviating Fedeficient responses [76]. In addition, an increase in the TCA related enzymes such as citrate synthase (CS), malate dehydrogenase $(\mathrm{MDH})$ and isocitrate dehydrogenase $\left(\mathrm{NADP}^{+}-\mathrm{IDH}\right)$ has been observed in the Fe deficiency several species [77]. However, until recently, there has been little information in the literature concerning the effect of $\mathrm{H}_{2} \mathrm{~S}$ signalling on organic acid metabolism. For instance, our previous study showed that $\mathrm{H}_{2} \mathrm{~S}$ effects Alinduced citrate secretion from barley root apices [28], suggesting that $\mathrm{H}_{2} \mathrm{~S}$ is responsible for changes in organic acid pools under certain stress conditions. In this study, our results clearly showed that, under Fe deficiency, NaHS influenced organic acid metabolism (citric acid and malic acid) and TCA cycles-related genes transcript levels including GmCS, GmACO, GmMDH, GmMS in soybean roots (Fig. 8). Similar results were also found in a study of silicon-alleviating Fe-deficient responses [76]. Above result showed that $\mathrm{H}_{2} \mathrm{~S}$ regulated the TCA related gene expression and organic acid synthesis, and further enhancing the adaption of Fe deficiency in soybean plants. Moreover, data from transcriptomic analyses regarding the impact of $\mathrm{H}_{2} \mathrm{~S}$ on Fe-deficient responses in soybean were scarce. An analysis in a recent study of soybean demonstrated that soybean should be used as a new model plant for understanding the Fe deficiency tolerance mechanism and found that a series of $\mathrm{Fe}$ acquirement-related genes are regulated by Fe deficiency [42]. Our results further demonstrate that $\mathrm{H}_{2} \mathrm{~S}$ signalling could directly or indirectly affect $\mathrm{Fe}$ acquisition and transport by controlling organic acid metabolism, as well as the transcriptional activation of Fe-deficient associated genes involved in the TCA cycle in soybean seedlings.

\section{Conclusion}

Based on the results shown herein and current knowledge of the mechanisms underlying plant responses to Fe deficiency, a signalling pathway by which $\mathrm{H}_{2} \mathrm{~S}$ improves the adaptation of soybean seedlings to Fe deficiency has been proposed. As shown in Fig. 9, the present results indicated that the role of $\mathrm{H}_{2} \mathrm{~S}$ in the alleviation of Fe deficiency chlorosis included an increase in apoplastic $\mathrm{Fe}$ and $\mathrm{Fe}$ accumulation in roots and leaves by regulating FCR activities and Fe homeostasis- and sulphur metabolism-related gene expression levels, thereby promoting plant photosynthesis and growth in soybean seedlings. In addition, exogenous $\mathrm{H}_{2} \mathrm{~S}$ changed the concentrations of plant hormones by modulating plant hormone-related gene expression abundances in soybean seedlings grown in a Fe-deficient solution. The biosynthesis of organic acid and related gene expression also played a vital role in modulating the $\mathrm{H}_{2} \mathrm{~S}$-mediated alleviation of Fe deficiency in soybean seedlings.

\section{Methods \\ Plant materials and growth conditions}

Soybean seeds (Glycine max L. Zhonghuang 13) were obtained from Henan Academy of Agricultural Sciences. Seeds were first sterilized in $75 \%$ ethanol for $3 \mathrm{~min}$, and then in a $10 \%$ sodium hypochlorite solution for an additional $10 \mathrm{~min}$, followed by washing with distilled water and germinated in soil (Pindstrup Mosebrug A/S, Denmark): vermiculite (1:1) mixture for $6 \mathrm{~d}$. Seedlings (six-day-old) were transferred to plastic pots (six seedlings per pot), which filled with $1.5 \mathrm{l}$ of nutrient solution. The composition of the nutrient solution was as follows: $0.25 \mathrm{mM} \mathrm{KH}_{2} \mathrm{PO}_{4}, 0.5 \mathrm{mM} \mathrm{MgSO} 4,0.5 \mathrm{mM} \mathrm{Ca}\left(\mathrm{NO}_{3}\right)_{2}$, and $1 \mathrm{mM} \mathrm{KNO}$; the composition of micronutrients was $10 \mu \mathrm{M} \mathrm{H}_{3} \mathrm{BO}_{3}, 0.5 \mu \mathrm{M} \mathrm{MnSO}_{4}, 0.5 \mu \mathrm{M} \mathrm{ZnSO}, 0.1$ $\mu \mathrm{M} \mathrm{CuSO}_{4}$, and $0.1 \mu \mathrm{M}\left(\mathrm{NH}_{4}\right)_{6} \mathrm{Mo}_{7} \mathrm{O}_{24}$. Iron was supplied as $50 \mu \mathrm{M} \mathrm{Fe(III)-EDTA.} \mathrm{Plants} \mathrm{were} \mathrm{grown} \mathrm{under}$ controlled environmental conditions in a growth chamber (Thermo Scientific, Thermo Fisher, USA) with a light/dark period of $14 / 10 \mathrm{~h}$, relative humidity of $70 \%$, temperature of $21 / 26^{\circ} \mathrm{C}$ (night/day) and a photosynthetically active radiation (PAR) of $280 \mu \mathrm{mol} \mathrm{m}^{-2} \mathrm{~s}^{-1}$.

Seedlings were pre-cultured for $7 \mathrm{~d}$ in nutrient solution supplied with $50 \mu \mathrm{M} \mathrm{Fe}(\mathrm{III})$-EDTA, and then grown for another $15 \mathrm{~d}$ in either a $+\mathrm{Fe}(50 \mu \mathrm{M})$ or $-\mathrm{Fe}(1 \mu \mathrm{M})$ nutrient solution with or without a supply of $100 \mu \mathrm{M}$ $\mathrm{NaHS},-\mathrm{Fe}, 1 \mu \mathrm{M}$ Fe; $-\mathrm{Fe}+\mathrm{NaHS}$, seedlings treated with $100 \mu \mathrm{M} \mathrm{NaHS}$ and $1 \mu \mathrm{M} \mathrm{Fe}+\mathrm{Fe}, 50 \mu \mathrm{M} \mathrm{Fe}+\mathrm{Fe}+\mathrm{NaHS}$, seedlings treated with $100 \mu \mathrm{M}$ NaHS and $50 \mu \mathrm{M}$ Fe. Every treatment consisted of twelve pots (three pots per replicate). Every treatment had four replicates. The $\mathrm{pH}$ of the nutrient solution was adjusted to 7.0 with a Delta $320 \mathrm{pH}$ electrode (Mettler Toledo, Zurich, Switzerland), 


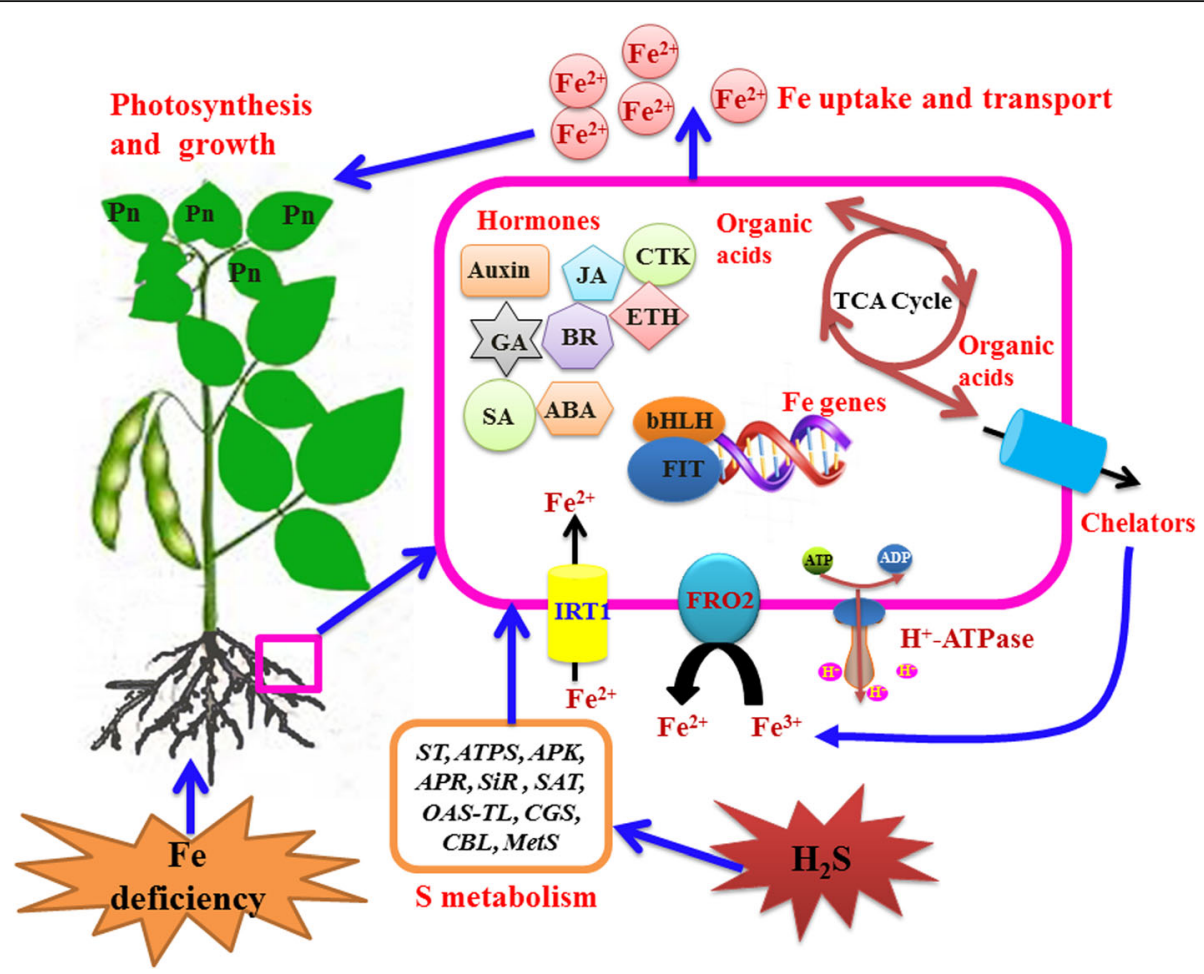

Fig. 9 A schematic model for $\mathrm{H}_{2} \mathrm{~S}$-alleviated iron deficiency in roots of Glycine max plants. CTK, cytokinin; GA, gibberellin; ABA, abscisic acid; ETH, ethylene; BR, brassinosteroid; JA, jasmonic acid; SA, salicylic acid; IRT1, iron regulator transporter; FRO2, ferric reduction oxidase 2; bHLH, basic helix-loop-helix protein; FIT; Pn, photosynthesis; ST, sulphate transporter; ATPS, ATP sulfurylase; APK, adenylylsulphate kinase; APR, phosphoadenosine phosphosulphate reductase; SiR, sulphite reductase; SAT, serine O-acetyltransferase; OAS-TL, O-acetylserine(thiol)lyase; CGS, cystathionine gamma-synthase; CBL, cystathionine beta-lyase; MetS, methionine synthase

and it was completely renewed every $4 \mathrm{~d}$ and continuously aerated.

\section{Chlorophyll determination}

The chlorophyll content was measured according to the method of Lichtenthaler [78]. Fresh soybean leaves $(0.2$ g) were powdered with liquid nitrogen, and four volumes of $80 \%(\mathrm{v} / \mathrm{v})$ aqueous acetone were used to extract the pigment until complete bleaching was observed. The total chlorophyll content was calculated from the OD absorbance of 470, 646, and $663 \mathrm{~nm}$.

\section{Fe content analysis}

For the total Fe content analysis, the harvested roots, stems and leaves were washed three times with $1.5 \mathrm{mM}$ $\mathrm{CaCl}_{2}$, and then a $\mathrm{H}_{2} \mathrm{SO}_{4}: \mathrm{H}_{2} \mathrm{O}_{2}$ (5:1) reagent mixture was used to digest the plant samples at $420^{\circ} \mathrm{C}$ in a digestion block. The total Fe concentrations were measured using an atomic absorption spectrophotometer (Hitachi Z2000, Hitachi, Japan) [10].

The apoplastic Fe content was analyzed according to Jin et al. [55]. Roots were transferred to a beaker containing $150 \mathrm{ml}$ of aerated $0.5 \mathrm{mM} \mathrm{CaSO}$ for $15 \mathrm{~min}$. Then the roots were put in a tube filled with $150 \mathrm{ml}$ of
$1.5 \mathrm{mM}$ 2.2-bipyridyl. The solution was bubbled with $\mathrm{N}_{2}$ for $5 \mathrm{~min}$ before and after the addition of $12.5 \mathrm{mM}$ $\mathrm{Na}_{2} \mathrm{~S}_{2} \mathrm{O}_{4}$ to displace oxygen. Finally, the solution of the $\mathrm{Fe}(\mathrm{II})$-bipyridyl complex was assayed spectrophotometrically at $520 \mathrm{~nm}$. The blank was measured without a sample.

\section{Solution $\mathrm{pH}$ measurement}

The $\mathrm{pH}$ of the nutrient solution was measured every $3 \mathrm{~d}$ with a Delta $320 \mathrm{pH}$ electrode (Mettler Toledo, Zurich, Switzerland).

\section{Root FCR activity measurement}

FCR activity was determined according to the method of Grusak [79]. Whole roots were placed in a test tube filled with $5 \mathrm{ml}$ of an assay solution. The assay solution was contained $0.5 \mathrm{mM} \mathrm{CaSO}, 0.1 \mathrm{mM}$ 4-morpholineethanesulfonic acid, $0.1 \mathrm{mM}$ bathophenanthrolinedisulfonic acid disodium salt hydrate (BPDS), and 100 $\mathrm{mM} \mathrm{Fe}(\mathrm{III})$-EDTA and the $\mathrm{pH}$ of assay solution was adjusted with $1 \mathrm{M} \mathrm{NaOH}$ to 5.5 . The tubes were placed in a dark room at $25^{\circ} \mathrm{C}$ for $1 \mathrm{~h}$, and swirled the rubes with hand for $10 \mathrm{~min}$ intervals. The assay solution was measured using a spectrophotometer at $535 \mathrm{~nm}$, and the 
concentration of $\mathrm{Fe}(\mathrm{III})[\mathrm{BPDS}]_{3}$ was calculated using an extinction coefficient of $22.14 \mathrm{mM}^{-1} \mathrm{~cm}^{-1}$. The data are recorded as the means of relative root FCR activity.

\section{Determination of endogenous $\mathrm{H}_{2} \mathrm{~S}, \mathrm{GSH}$, and non-protein thiols content}

Endogenous $\mathrm{H}_{2} \mathrm{~S}$ content was determined according to the method described by Sekiya et al. and Chen et al. [39, 80] with some minor modifications. The reduced GSH content was determined with a GSH reagent kit (Jiancheng Bioengineering Institute, Nanjing, China) according to the method described by Chen et al. [28]. The total content of nonprotein thiols (NPTs) was analysed according to Del Longo et al. [81] with some modifications.

\section{RNA extraction, sequencing and library construction}

Soybean root samples treated with $-\mathrm{Fe},-\mathrm{Fe}+\mathrm{NaHS}$, $+\mathrm{Fe}$, and $+\mathrm{Fe}+\mathrm{NaHS}$ for $15 \mathrm{~d}$ were used for RNA-Seq analysis. The transcriptome experiment was conducted with the assistance of Beijing Novogene Corporation according to the method of Wang et al. [82]. For each treatment, three individual roots were pooled together in equal amounts to generate one mixed sample, and three biological replicates were assessed for each treatment in the RNA-Seq analysis.

A total amount of $5 \mu \mathrm{g}$ RNA per sample was used as input material for the RNA sample preparations. All samples had RIN values above 8.0. Sequencing libraries were generated using the Illumina TruSeq ${ }^{\text {TM }}$ RNA Sample Preparation Kit (Illumina, San Diego, CA, USA) according to the manufacturer's instructions. Raw image data generated from the sequencing were transformed by base calling into sequence data, which were called raw data/ raw reads and were stored in fastq format [83]. The Q20, Q30, and GC content and sequence duplication level of the clean data were simultaneously calculated. All the downstream analyses were based on high-quality clean data.

\section{GO and KEGG pathway}

The gene ontology (GO) from the soybean genome annotation was used for the functional classification of differentially expressed genes (DEGs) according to the method of Wang et al. [82]. GO terms with corrected $P$ values $<0.05$ were considered significantly enriched by DEGs.

KEGG is a database resource for understanding the high-level functions and utilities of the biological systems. The pathway is the major public pathway-related database for enrichment analysis, such as http://www. genome.jp.kegg/.

\section{Determination of plant hormones}

Plant hormones were extracted from samples using the hormone extraction kit following the manufacturer's instructions (Comin Biotechnology Co.Ltd., Suzhou, China, www.cominbio.com).

For ABA determination, fresh leaf and root tissues ( $100 \mathrm{mg}$ ) were sealed in $2 \mathrm{ml}$ tubes containing $1 \mathrm{ml}$ of extraction buffer reagent I with ABA standards. The mixtures were gently agitated overnight at $4{ }^{\circ} \mathrm{C}$ and then centrifuged at $8000 \mathrm{~g}$ for $10 \mathrm{~min}$. The upper phase was collected, and then $0.5 \mathrm{ml}$ reagent II was added for decolorization by extraction three times. The water phase was adjusted to $\mathrm{pH}$ 2.8 , combined with the organic phase in the upper layer, and then dried with a nitrogen blower. The mobile phase consisted of a constant volume of $0.5 \mathrm{ml}$, and the needle filter was filtered in the sample bottle for testing. Ten microliters of each sample was injected into a Kromasil C18 reversed-phase column $(250 \mathrm{~mm} \times 4.6 \mathrm{~mm})$ and analysed using an HPLC system (Rigol L3000, RIGOL, Beijing, China). The mobile phase included methanol and $1 \%$ acetic acid aqueous solution. The column temperature was $30^{\circ} \mathrm{C}$ and the flow rate was $0.8 \mathrm{ml} / \mathrm{min}$. The UV detection wavelength was $254 \mathrm{~nm}$, and the sampling time was $35 \mathrm{~min}$. At least three independent biological replicates of each sample were performed.

For ZA and GA determination, the extraction method was the same as ABA. Ten microliters of each sample were injected into a Kromasil C18 reversed-phase column $(250 \mathrm{~mm} \times 4.6 \mathrm{~mm})$ and analysed using an HPLC system (Rigol L3000, RIGOL, Beijing, China). The mobile phase included methanol and $1 \%$ acetic acid aqueous solution. The column temperature was $30^{\circ} \mathrm{C}$, the flow rate was $1 \mathrm{ml} / \mathrm{min}$, the UV detection wavelength was $254 \mathrm{~nm}$, and the sampling time was $40 \mathrm{~min}$. At least three independent biological replicates of each sample were performed.

For IAA determination, the extraction method was the same as for ABA. Ten microliters of each sample was injected into a Kromasil $\mathrm{C} 18$ reversed-phase column $(250 \mathrm{~mm} \times 4.6 \mathrm{~mm})$ and analysed using an HPLC system (Rigol L3000, RIGOL, Beijing, China). The mobile phase included methanol and ultra-pure water $(400 \mathrm{ml}: 600 \mathrm{ml})$. The column temperature was $30^{\circ} \mathrm{C}$, the flow rate was $0.8 \mathrm{ml} / \mathrm{min}$, and the sampling time was $40 \mathrm{~min}$. The excitation wavelength was $275 \mathrm{~nm}$ and the emission wavelength was $345 \mathrm{~nm}$. At least three independent biological replicates of each sample were performed.

For JA determination, the extraction method was the same as for ABA. Ten microliters of each sample were injected into a Kromasil C18 reversed-phase column $(250 \mathrm{~mm} \times 4.6 \mathrm{~mm})$ and analysed using an HPLC system (Rigol L3000, RIGOL, Beijing, China). The mobile phase included methanol and $0.1 \%$ aqueous formic acid. The column temperature was $35^{\circ} \mathrm{C}$, the flow rate was $0.8 \mathrm{ml} /$ min, and the sampling time was $40 \mathrm{~min}$. The UV wavelength was $230 \mathrm{~nm}$. At least three independent biological replicates of each sample were performed. 
For SA determination, fresh leaf and root tissues ( $100 \mathrm{mg}$ ) were ground with a mortar and added to $1 \mathrm{ml}$ of precooled reagent $\mathrm{I}$ and extracted overnight at $4{ }^{\circ} \mathrm{C}$. After centrifugation $8000 \mathrm{~g}$ for $10 \mathrm{~min}$, the supernatant was collected and then the residue extracted with $0.5 \mathrm{ml}$ reagent for $2 \mathrm{~h}$. The supernatant was removed and combined three times, and then it was evaporated to no organic phase at $40^{\circ} \mathrm{C}$ and added $20 \mu \mathrm{l}$ reagent II with shaking for $1 \mathrm{~min}$. Reagent III $(1 \mathrm{ml})$ was added three times for extraction and transferred the upper organic phase in a new EP tube, dried with nitrogen, and supplemented with $0.5 \mathrm{ml}$ of the mobile phase for dissolution. The samples were filtered with a needle filter. The test result was free SA. Then, $0.5 \mathrm{ml}$ of reagent IV was added to the lower water phase, with shaking for $1 \mathrm{~h}$, followed by the addition of $1 \mathrm{ml}$ reagent III and $0.5 \mathrm{ml}$ of mobile phase for dissolution. The remaining result was bound SA. Ten microliters of each sample was injected into a Kromasil C18 reverse-phase column $(250 \mathrm{~mm} \times 4.6 \mathrm{~mm})$ and analysed using an HPLC system (Rigol L3000, RIGOL, Beijing, China). The mobile phase included 1\% acetic acid aqueous solution and methanol (40:60). The column temperature was $35^{\circ} \mathrm{C}$, the flow rate was $0.8 \mathrm{ml} /$ $\mathrm{min}$, and the sampling time was $40 \mathrm{~min}$. The excitation wavelength was $294 \mathrm{~nm}$, and the emission wavelength was $426 \mathrm{~nm}$. At least three independent biological replicates of each sample were performed.

\section{Determination of citric acid and malic acid contents}

The fresh leaf and root were used to measure the citric acid and malic acid contents [76]. The samples $(\sim 100 \mathrm{mg})$ were immediately frozen in liquid $\mathrm{N}_{2}$, and ground thoroughly and extracted with $1 \mathrm{ml}$ of a methanol: deionized $\mathrm{H}_{2} \mathrm{O}(3: 1 ; \mathrm{v} / \mathrm{v})$ mixture. All the samples were filtered with $0.22 \mu \mathrm{m}$-pore-size nylon syringe filters (Phenomenex, Torrance, CA, USA) before the analyses. The extract was mixed with methanol $(3: 1 ; \mathrm{v} / \mathrm{v})$ and analyzed using an HPLC system (Agilent 1100, Agilent, SC, USA) containing a Kromasil C18 reversed-phase column $(250 \mathrm{~mm} \times 4.6$ $\mathrm{mm})$ to separate citric acid and malic acid from different samples. The column temperature, the flow rate, and the sampling time were $25^{\circ} \mathrm{C}, 0.8 \mathrm{ml} / \mathrm{min}$, and $20 \mathrm{~min}$, respectively. The array detector was set at $214 \mathrm{~nm}$.

\section{Validation of the mRNA-Seq data using qRT-PCR}

To confirm of the RNA-Seq data, some different key genes was performed using qRT-PCR. Total RNAs were reverse-transcribed into first-strand cDNAs with $\mathrm{M}$ MLV reverse transcriptase (TaKaRa, Dalian, China) according to the method of Chen et al. (2011). The $20 \mu \mathrm{l}$ qRT-PCR reaction mixture contained the following: $1 \mu \mathrm{l}$ of forward and reverse primers, including iron homeostasis-related genes, sulphur metabolism-related genes, plant hormone-related genes, and organic acid synthesis-related genes (Table S3), $2 \mu \mathrm{l}$ of cDNA, and $10 \mu \mathrm{l}$ of Faststart Universal SYBR Green Master (ROX, Mannheim, Germany). The amplification and detection of the dsDNA synthesis of these genes were performed using the PCR conditions as described in Table S4. Each sample had three independent replicates. The relative gene expression levels were calculated using the comparative threshold cycle $(\mathrm{Ct})$ method. GmEIF1B and Gmactin were the internal control. The mRNA transcriptional abundance value of genes is expressed as $2^{-\Delta \Delta \mathrm{Ct}}$ [84]. The QuantStudio 6 Flex qRT-PCR System (Life Technologies, Thermos, USA) was used to perform the qRT-PCR.

\section{Statistical analysis}

For dry weight, the $\mathrm{pH}$ of the root bathing solution, and chlorophyll fluorescence parameters, twenty replicates were used. For the physiological and biochemical analyses, at least three replicates were conducted. Every experiment contained three biological replicates. Statistical significance was tested using one-way or two-way ANOVA in SPSS 13.0 (SPSS Inc., Chicago, IL), and the results are expressed as the mean value \pm SE. Post hoc comparisons were conducted using the Tukey test at a significance level of $P<0.05$.

\section{Supplementary information}

Supplementary information accompanies this paper at https://doi.org/10. 1186/s12870-020-02601-2.

\footnotetext{
Additional file 1. Materials and Methods. Figure S1. $\mathrm{H}_{2} \mathrm{~S}$ but not other sulphur- or sodium-containing compounds derived from NaHS contributed to increased chlorophyll concentration in iron deficiency Glycine max seedlings. Glycine max seedlings were treated with $100 \mu \mathrm{M}$ of different sulphur compounds including $\mathrm{NaHS}, \mathrm{Na}_{2} \mathrm{~S}_{1} \mathrm{Na}_{2} \mathrm{SO}_{4}, \mathrm{Na}_{2} \mathrm{SO}_{3}, \mathrm{NaHSO}_{4}$, $\mathrm{NaHSO}_{3}$, and $\mathrm{NaAC}$ for $15 \mathrm{~d}$ under iron deficiency condition (-Fe, $1 \mu \mathrm{M}$ Fe). Figure S2. Effect of NaHS on the nodule number and nodule dry weight of iron-deficient Glycine max plants. The 3-w-old Glycine max seedlings were treated with the nutrition solution containing $1 \mu \mathrm{M} \mathrm{Fe}($ III)EDTA or $50 \mu \mathrm{M}$ Fe(III)-EDTA with or without $100 \mu \mathrm{M}$ NaHS for 15 days. Error bars represents the mean $\pm \mathrm{SE}$. Columns labelled with different letters indicate significant differences with $P<0.05$. Figure S3. Effect of NaHS on net photosynthesis (Pn) (A), stomatal conductance (Gs) (B), intrancellular $\mathrm{CO}_{2}$ concentration (Ci) (C), and water use efficiency (WUE) (D) of iron-deficient Glycine max plants. The 3-w-old Glycine max seedlings were treated with the nutrition solution containing $1 \mu \mathrm{M} \mathrm{Fe}($ III)-EDTA or $50 \mu \mathrm{M}$ Fe(III)-EDTA with or without $100 \mu \mathrm{M}$ NaHS for 15 days. Error bars represents the mean $\pm \mathrm{SE}$. $-\mathrm{Fe}, 1 \mu \mathrm{M} \mathrm{Fe} ;-\mathrm{Fe}+\mathrm{NaHS}$, seedlings treated with $100 \mu \mathrm{M} \mathrm{NaHS}$ and $1 \mu \mathrm{M} \mathrm{Fe}$; $+\mathrm{Fe}, 50 \mu \mathrm{M}$ Fe; +Fe + NaHS, seedlings treated with $100 \mu \mathrm{M}$ NaHS and $50 \mu \mathrm{M}$ Fe. Figure S4. Effect of NaHS on photosystem II (PSII) (A), electronic transport ratio (ETR) (B), Fv/Fm (C), and Fv'/Fm ' (D) of iron-deficient Glycine max plants. The 3-w-old Glycine max seedlings were treated with the nutrition solution containing $1 \mu \mathrm{M}$ Fe(III)-EDTA or $50 \mu \mathrm{M}$ Fe(III)-EDTA with or without $100 \mu \mathrm{M}$ NaHS for 15 days. Error bars represents the mean \pm SE. Columns labelled with different letters indicate significant differences with $P<0.05$. $-\mathrm{Fe}, 1 \mu \mathrm{M} \mathrm{Fe} ;-\mathrm{Fe}+$ $\mathrm{NaHS}$, seedlings treated with $100 \mu \mathrm{M} \mathrm{NaHS}$ and $1 \mu \mathrm{M} \mathrm{Fe}$; Fe, $50 \mu \mathrm{M} \mathrm{Fe}$; $+\mathrm{Fe}+\mathrm{NaHS}$, seedlings treated with $100 \mu \mathrm{M}$ NaHS and $50 \mu \mathrm{M}$ Fe. Figure S5. Effect of NaHS on the $\mathrm{Cu}(\mathrm{A}-\mathrm{C}), \mathrm{Mn}(\mathrm{D}-\mathrm{F})$, and $\mathrm{Zn}(\mathrm{G}-\mathrm{I})$ concentrations of iron-deficient Glycine max plants. The 3-w-old Glycine max seedlings were treated with the nutrition solution containing $1 \mu \mathrm{M}$ Fe(III)-EDTA or
} 
$50 \mu \mathrm{M}$ Fe(III)-EDTA with or without $100 \mu \mathrm{M}$ NaHS for 15 days. Error bars represents the mean \pm SE. Columns labelled with different letters indicate significant differences with $P<0.05$. Figure S6. The correlation test of transcriptome sequencing data of Glycine max roots. There are three biological repeats per treatment. $-\mathrm{Fe}, 1 \mu \mathrm{M} \mathrm{Fe} ;-\mathrm{Fe}+\mathrm{NaHS}$, seedlings treated with $100 \mu \mathrm{M} \mathrm{NaHS}$ and $1 \mu \mathrm{M} \mathrm{Fe}$; $+\mathrm{Fe}, 50 \mu \mathrm{M} \mathrm{Fe}$; $+\mathrm{Fe}+\mathrm{NaHS}$, seedlings treated with $100 \mu \mathrm{M} \mathrm{NaHS}$ and $50 \mu \mathrm{M}$ Fe. Figure S7. Volcano plot showing DEGs in Glycine max seedling treated with NaHS under iron deficiency condition. Biological significant ( $\log _{2}$ fold change) is depicted on the $x$ axis and statistical significant $\left(\log _{10}\right)$ is depicted on the $y$ axis. Statistical significance was corrected at $P<0.05$. (A) $-\mathrm{Fe}+\mathrm{NaHS}$ vs $-\mathrm{Fe}$; (B) + $\mathrm{Fe}+\mathrm{NaHS}$ vs + Fe; (C) $-\mathrm{Fe}$ vs + Fe; (D) + Fe + NaHS vs $-\mathrm{Fe}+\mathrm{NaHS}$. $-\mathrm{Fe}$ $1 \mu \mathrm{M} \mathrm{Fe} ;-\mathrm{Fe}+\mathrm{NaHS}$, seedlings treated with $100 \mu \mathrm{M}$ NaHS and $1 \mu \mathrm{M}$ Fe; $+\mathrm{Fe}, 50 \mu \mathrm{M} \mathrm{Fe} ;+\mathrm{Fe}+\mathrm{NaHS}$, seedlings treated with $100 \mu \mathrm{M} \mathrm{NaHS}$ and $50 \mu \mathrm{M}$ Fe. Figure S8. Significantly enriched gene ontology $(\mathrm{GO})$ terms $(P<0.05)$ in the gene expression numbers in the root of Glycine max treated with $\mathrm{NaHS}$ under iron deficiency condition. (A) the up-regulated genes under $-\mathrm{Fe}+\mathrm{NaHS}$ vs $-\mathrm{Fe}$ condition; (B) the down-regulated genes under $-\mathrm{Fe}+\mathrm{NaHS}$ vs $-\mathrm{Fe}$ condition; (C) the up-regulated genes under $+\mathrm{Fe}+\mathrm{NaHS}$ vs + Fe condition; (D) the down-regulated genes under $+\mathrm{Fe}+$ $\mathrm{NaHS}$ vs + Fe condition. GO terms belong to biological processes, molecular functions, and cellular components were shown in green, blue, and organ, respectively. Table S1. Summary of transcriptome sequencing data of Glycine max roots treated with NaHS under iron deficiency condition. $-\mathrm{Fe}, 1 \mu \mathrm{M} \mathrm{Fe} ;-\mathrm{Fe}+\mathrm{NaHS}$, seedlings treated with $100 \mu \mathrm{M} \mathrm{NaHS}$ and $1 \mu \mathrm{M} \mathrm{Fe} ;+\mathrm{Fe}, 50 \mu \mathrm{M} \mathrm{Fe} ;+\mathrm{Fe}+\mathrm{NaHS}$, seedlings treated with $100 \mu \mathrm{M} \mathrm{NaHS}$ and $50 \mu \mathrm{M}$ Fe. Table S2. Statistics of genes in different expression-level interval of Glycine max roots treated with NaHS under iron deficiency condition. $-\mathrm{Fe}, 1 \mu \mathrm{M} \mathrm{Fe}$; $-\mathrm{Fe}+\mathrm{NaHS}$, seedlings treated with $100 \mu \mathrm{M}$ NaHS and $1 \mu \mathrm{M} \mathrm{Fe} ;+\mathrm{Fe}, 50 \mu \mathrm{M} \mathrm{Fe} ;+\mathrm{Fe}+\mathrm{NaHS}$, seedlings treated with $100 \mu \mathrm{M}$ $\mathrm{NaHS}$ and $50 \mu \mathrm{M}$ Fe. Table S3. Sequences of forward and reverse primers used in qRT-PCR for gene expression analysis in roots of Glycine max seedling under iron deficiency condition. Table S4. Procedures of dsDNA synthesis used in qRT-PCR for gene expression analysis in roots of Glycine max seedlings under iron deficiency condition. Table S5. Iron assimilation-related gene expression levels using transcriptome in Glycine max roots treated with $\mathrm{NaHS}$ under iron deficiency condition. $-\mathrm{Fe}, 1 \mu \mathrm{M}$ $\mathrm{Fe} ;-\mathrm{Fe}+\mathrm{NaHS}$, seedlings treated with $100 \mu \mathrm{M} \mathrm{NaHS}$ and $1 \mu \mathrm{M} \mathrm{Fe}+\mathrm{Fe}$ $50 \mu \mathrm{M} \mathrm{Fe} ;+\mathrm{Fe}+\mathrm{NaHS}$, seedlings treated with $100 \mu \mathrm{M} \mathrm{NaHS}$ and $50 \mu \mathrm{M}$ Fe. Table S6. Sulfur assimilation-related gene expression levels using transcriptome in Glycine max roots treated with $\mathrm{NaHS}$ under iron deficiency condition. $-\mathrm{Fe}, 1 \mu \mathrm{M} \mathrm{Fe}$; $-\mathrm{Fe}+\mathrm{NaHS}$, seedlings treated with $100 \mu \mathrm{M} \mathrm{NaHS}$ and $1 \mu \mathrm{M} \mathrm{Fe} ;+\mathrm{Fe}, 50 \mu \mathrm{M} \mathrm{Fe} ;+\mathrm{Fe}+\mathrm{NaHS}$, seedlings treated with $100 \mu \mathrm{M} \mathrm{NaHS}$ and $50 \mu \mathrm{M}$ Fe. Table S7. Plant hormones-related gene expression levels using transcriptome in Glycine max roots treated with $\mathrm{NaHS}$ under iron deficiency condition. $-\mathrm{Fe}, 1 \mu \mathrm{M} \mathrm{Fe} ;-\mathrm{Fe}+\mathrm{NaHS}$, seedlings treated with $100 \mu \mathrm{M} \mathrm{NaHS}$ and $1 \mu \mathrm{M} \mathrm{Fe}+\mathrm{Fe}, 50 \mu \mathrm{M} \mathrm{Fe} ;+\mathrm{Fe}+$ $\mathrm{NaHS}$, seedlings treated with $100 \mu \mathrm{M}$ NaHS and $50 \mu \mathrm{M}$ Fe. Table S8. Organic acid-related gene expression levels using transcriptome in Glycine max roots treated with $\mathrm{NaHS}$ under iron deficiency condition. -Fe, $1 \mu \mathrm{M}$ Fe; $-\mathrm{Fe}+\mathrm{NaHS}$, seedlings treated with $100 \mu \mathrm{M} \mathrm{NaHS}$ and $1 \mu \mathrm{M} \mathrm{Fe} ;+\mathrm{Fe}, 50 \mu \mathrm{M}$ $\mathrm{Fe} ;+\mathrm{Fe}+\mathrm{NaHS}$, seedlings treated with $100 \mu \mathrm{M} \mathrm{NaHS}$ and $50 \mu \mathrm{M} \mathrm{Fe}$

\section{Abbreviations}

CTK: Cytokinin; GA: Gibberellin; ABA: Abscisic acid; ETH: Ethylene; BR: Brassinosteroid; JA: Jasmonic acid; SA: Salicylic acid; IRT1: Iron regulator transporter; FRO2: Ferric reduction oxidase 2; bHLH: basic helix-loop-helix protein; Pn: Photosynthesis; WUE: Water use efficiency; ST: Sulfate transporter; ATPS: ATP sulfurylase; APK: Adenylylsulphate kinase; APR: Phosphoadenosine phosphosulphate reductase; SiR: Sulphite reductase; SAT: Serine Oacetyltransferase; OAS-TL: O-acetylserine(thiol)lyase; CGS: Cystathionine gamma-synthase; CBL: Cystathionine beta-lyase; MetS: Methionine synthase

\section{Acknowledgements}

We acknowledgement and thank Prof. Hai-Lei Zheng from Xiamen University, China for providing critical suggestions and valuable comments to improve this manuscript.

\section{Authors' contributions}

$J C$ performed all experiments, analyzed the data and wrote manuscript. NNZ, QP and XYL assisted with the experiments. ZPSG and JHZ help to revise the manuscript. JC and GHW planned and designed the study and wrote and revised the manuscript. It is to mention that all authors read and approved the manuscript.

\section{Funding}

This study was financially supported by the Natural Science Foundation of China (NSFC) (31501822) and the Postdoctoral Science Foundation of China (2015 M580876 and 2016 T90948), and the Hong Kong Research Grant Council (14122415, 14160516, 14177617, AoE/M-05/12, AoE/M-403/16). The funding bodies were not involved in the design of the study, collection, analysis, and interpretation of data, and in writing the manuscript.

\section{Availability of data and materials}

Our raw Illumina sequence data were deposited in the National Center for Biotechnology Information (NCBI) and be accessed in the sequence read archive (SRA) database (http://www.ncbi.nlm.nih.gov/sra). The accession number is PRJNA655258 (https://www.ncbi.nlm.nih.gov/bioproject/ PRJNA655258), which includes 12 accession items (SAMN15731791SAMN15731802). All data generated or analysed during this study are included in this published article and the supplementary information files.

\section{Ethics approval and consent to participate}

Not applicable.

\section{Consent for publication}

Not applicable.

\section{Competing interests}

The authors declare that this research was conducted in the absence of any commercial or financial relationships that could be construed as a potential conflict of interest. All the authors declare that they have no competing interests.

\section{Author details}

${ }^{1}$ State Key Laboratory of Soil Erosion and Dryland Farming on the Loess Plateau, Northwest A\&F University, Yangling, Shaanxi 712100, P.R. China. ${ }^{2}$ School of Life Sciences and State Key Laboratory of Agrobiotechnology, the Chinese University of Hong Kong, Shatin, Hong Kong. ${ }^{3}$ Department of Biology, Hong Kong Baptist University, Kowloon Tong, Hong Kong.

Received: 24 October 2019 Accepted: 16 August 2020

Published online: 20 August 2020

\section{References}

1. Guerinot ML. Improving rice yields-ironing out the details. Nature Biotech. 2001;19:417

2. $\quad$ Curie C, Mari S. New routes for plant iron mining. New Phytol. 2017;214(2): $521-5$

3. Brumbarova T, Bauer $P$, Ivanov R. Molecular mechanisms governing Arabidopsis iron uptake. Trends Plant Sci. 2015;20(2):124-33.

4. Ramirez L, Simontacchi M, Murgia I, Zabaleta E, Lamattina L. Nitric oxide, nitrosyl iron complexes, ferritin and frataxin: a well equipped team to preserve plant iron homeostasis. Plant Sci. 2011;181(5):582-92.

5. Tsai HH, Schmidt W. One way. Or another? Iron uptake in plants. New Phytol. 2017;214(2):500-5.

6. Lucena JJ, Hernandez-Apaolaza L. Iron nutrition in plants: an overview. Plant Soil. 2017:418(1-2):1-4

7. Curie C, Briat J-F. Iron transport and signaling in plants. Ann Rev Plant Biol. 2003:54(1):183-206.

8. Walker EL, Connolly EL. Time to pump iron: iron-deficiency-signaling mechanisms of higher plants. Curr Opin Plant Biol. 2008:11(5):530-5.

9. Ma JF. Plant root responses to three abundant soil minerals: silicon, aluminum and iron. Crit Rev Plant Sci. 2005;24(4):267-81.

10. Chen J, Wu FH, Shang YT, Wang WH, Hu WJ, Simon M, Liu X, Shangguan ZP, Zheng HL. Hydrogen sulphide improves adaptation of Zea mays seedlings to iron deficiency. J Exp Bot. 2015;66(21):6605-22. 
11. Graziano M, Lamattina L. Nitric oxide accumulation is required for molecular and physiological responses to iron deficiency in tomato roots. Plant J. 2007;52(5):949-60.

12. Liang $G$, Zhang HM, Li XL, Ai Q, Yu DQ. bHLH transcription factor bHLH115 regulates iron homeostasis in Arabidopsis thaliana. J Exp Bot. 2017;68(7): 1743-55.

13. Briat JF. Roles of ferritin in plants. J Plant Nutri. 1996;19(8-9):1331-42.

14. Petit JM, van Wuytswinkel $\mathrm{O}$, Briat JF, Lobréaux S. Characterization of an iron-dependent regulatory sequence involved in the transcriptional control of AtFerland ZmFerl plant ferritin genes by iron. J Biol Chem. 2001;276(8): 5584-90.

15. Briat JF, Ravet K, Arnaud N, Duc C, Boucherez J, Touraine B, Cellier F, Gaymard F. New insights into ferritin synthesis and function highlight a link between iron homeostasis and oxidative stress in plants. Ann Bot. 2010; 105(5):811-22.

16. Li GJ, Song HY, Li BH, Kronzucker HJ, Shi WM. Auxin resistant1 and PINFORMED2 protect lateral root formation in Arabidopsis under iron stress. Plant Physiol. 2015;169(4):2608-23.

17. Schmidt W, Schikora A. Different pathways are involved in phosphate and iron stress-induced alterations of root epidermal cell development. Plant Physiol. 2001;125(4):2078-84.

18. García MJ, Lucena C, Romera FJ, Alcántara E, Pérez-Vicente R. Ethylene and nitric oxide involvement in the up-regulation of key genes related to iron acquisition and homeostasis in Arabidopsis. J Exp Bot. 2010;61(14):3885-99.

19. Lucena C, Waters BM, Romera FJ, García MJ, Morales M, Alcántara E, PérezVicente R. Ethylene could influence ferric reductase, iron transporter, and $\mathrm{H}^{+}$-ATPase gene expression by affecting FER (or FER-like) gene activity. J Exp Bot. 2006;57(15):4145-54

20. Lei GJ, Zhu XF, Wang ZW, Dong F, Dong NY, Zheng SJ. Abscisic acid alleviates iron deficiency by promoting root iron reutilization and transport from root to shoot in Arabidopsis. Plant Cell Environ. 2014;37(4):852-63.

21. Séguéla $M$, Briat J-F, Vert $G$, Curie $C$. Cytokinins negatively regulate the root iron uptake machinery in Arabidopsis through a growth-dependent pathway. Plant J. 2008;55(2):289-300.

22. Hindt MN, Guerinot ML. Getting a sense for signals: regulation of the plant iron deficiency response. BBA Mole Cell Res. 2012;1823(9):1521-30.

23. Maurer F, Müller S, Bauer P. Suppression of Fe deficiency gene expression by jasmonate. Plant Physiol Bioch. 2011;49(5):530-6.

24. Wang B, Li G, Zhang W-H. Brassinosteroids are involved in Fe homeostasis in rice (Oryza sativa L.). J Exp Bot. 2015;66(9):2749-61

25. Shen C, Yang Y, Liu K, Zhang L, Guo H, Sun T, Wang H. Involvement of endogenous salicylic acid in iron-deficiency responses in Arabidopsis. J Exp Bot. 2016;67(14):4179-93.

26. Baudouin E, Poilevey A, Hewage NI, Cochet F, Puyaubert J, Bailly C. The significance of hydrogen sulfide for Arabidopsis seed germination. Front Plant Sci. 2016;7:930.

27. Ali B, Qian P, Sun R, Faroog MA, Gill RA, Wang J, Azam M, Zhou W. Hydrogen sulfide alleviates the aluminum-induced changes in Brassica napus as revealed by physiochemical and ultrastructural study of plant. Environ Sci Poll Res. 2015;22(4):3068-81.

28. Chen J, Wang WH, Wu FH, You CY, Liu TW, Dong XJ, He JX, Zheng HL. Hydrogen sulfide alleviates aluminum toxicity in barley seedlings. Plant Soil. 2013;362(1-2):301-18.

29. Hu H, Liu D, Li P, Shen W. Hydrogen sulfide delays leaf yellowing of stored water spinach (Ipomoea aquatica) during dark-induced senescence by delaying chlorophyll breakdown, maintaining energy status and increasing antioxidative capacity. Posth Biol Technol. 2015;108:8-20.

30. Zhang H, Ye YK, Wang SH, Luo JP, Tang J, Ma DF. Hydrogen sulfide counteracts chlorophyll loss in sweetpotato seedling leaves and alleviates oxidative damage against osmotic stress. Plant Growth Regul. 2009;58(3):243-50.

31. Chen J, Wang WH, Wu FH, He EM, Liu X, Shangguan ZP, Zheng HL. Hydrogen sulfide enhances salt tolerance through nitric oxide-mediated maintenance of ion homeostasis in barley seedling roots. Sci Rep. 2015;5: 12516.

32. Mostofa MG, Saegusa D, Fujita M, Tran LSP. Hydrogen sulfide regulates sal tolerance in rice by maintaining $\mathrm{Na}^{+} / \mathrm{K}^{+}$balance, mineral homeostasis and oxidative metabolism under excessive salt stress. Front Plant Sci. 2015;6:14

33. Chen J, Shang YT, Wang WH, Chen XY, He EM, Zheng HL, Shangguan ZP. Hydrogen sulfide-mediated polyamines and sugar changes are involved in hydrogen sulfide-induced drought tolerance in Spinacia oleracea seedlings. Front Plant Sci. 2016;7:1173.
34. Liu X, Chen J, Wang GH, Wang WH, Shen ZJ, Luo MR, Gao GF, Simon M, Ghoto K, Zheng HL. Hydrogen sulfide alleviates zinc toxicity by reducing zinc uptake and regulating genes expression of antioxidative enzymes and metallothioneins in roots of the cadmium/zinc hyperaccumulator Solanum nigrum L. Plant Soil. 2015;400:177-92.

35. Shi H, Ye T, Chan Z. Nitric oxide-activated hydrogen sulfide is essential for cadmium stress response in bermudagrass (Cynodon dactylon (L). Pers.). Plant Physiol Bioch. 2014;74:99-107.

36. Qiao Z, Jing T, Liu Z, Zhang $L$, Jin Z, Liu D, Pei $Y$. $H_{2} S$ acting as a downstream signaling molecule of $\mathrm{SA}$ regulates $\mathrm{cd}$ tolerance in Arabidopsis. Plant Soil. 2015;393(1-2):137-46.

37. Li ZG, Zhu LP. Hydrogen sulfide donor sodium hydrosulfide-induced accumulation of betaine is involved in the acquisition of heat tolerance in maize seedlings. Braz J Bot. 2015;38(1):31-8.

38. García-Mata C, Lamattina L. Hydrogen sulphide, a novel gasotransmitter involved in guard cell signalling. New Phytol. 2010;188(4):977-84.

39. Chen J, Wu FH, Wang WH, Zheng CJ, Lin GH, Dong XJ, He JX, Pei ZM, Zheng HL. Hydrogen sulphide enhances photosynthesis through promoting chloroplast biogenesis, photosynthetic enzyme expression, and thiol redox modification in Spinacia oleracea seedlings. J Exp Bot. 2011;62(13):4481-93.

40. Graziano M, Beligni MV, Lamattina L. Nitric oxide improves internal iron availability in plants. Plant Physiol. 2002;130(4):1852-9.

41. Hosoki R, Matsuki $N$, Kimura $H$. The possible role of hydrogen sulfide as an endogenous smooth muscle relaxant in synergy with nitric oxide. Bioch Biophy Res Commun. 1997;237(3):527-31.

42. Aksoy E, Maqbool A, Tindas I, Caliskan S. Soybean: a new frontier in understanding the iron deficiency tolerance mechanisms in plants. Plant Soil. 2017:418(1-2):37-44.

43. Naeve SL. Iron deficiency chlorosis in soybean. Agron J. 2006;98(6):1575-81.

44. Roriz M, Carvalho SMP, Vasconcelos MW. High relative air humidity influences mineral accumulation and growth in iron deficient soybean plants. Front Plant Sci. 2014:5:726.

45. Tiwari A, Mamedov F, Grieco M, Suorsa M, Jajoo A, Styring S, Tikkanen M, Aro EM. Photodamage of iron-Sulphur clusters in photosystem I induces non-photochemical energy dissipation. Nat Plants. 2016;2(4):9.

46. Rotaru $V$, Sinclair TR. Interactive influence of phosphorus and iron on nitrogen fixation by soybean. Environ Exp Bot. 2009;66(1):94-9.

47. Slatni T, Ben Salah I, Kouas S, Abdelly C. The role of nodules in the tolerance of common bean to iron deficiency. J Plant Res. 2014;127(3):455-65.

48. Slatni T, Krouma A, Aydi S, Chaiffi C, Gouia H, Abdelly C. Growth, nitrogen fixation and ammonium assimilation in common bean (Phaseolus vulgaris $\mathrm{L}$ ) subjected to iron deficiency. Plant Soil. 2008;312(1/2):49-57.

49. Xu K, Li ZK, Liu SW, Qiu BS. Effects of iron deficiency on the growth and photosynthesis of three bloom-forming cyanobacterial species isolated from Lake Taihu. Phycol Res. 2017:65(2):151-9.

50. Larbi A, Abadia A, Abadia J, Morales F. Down co-regulation of light absorption, photochemistry, and carboxylation in Fe-deficient plants growing in different environments. Photosynth Res. 2006;89(2-3):113-26.

51. Hantzis LJ, Kroh GE, Jahn CE, Cantrell M, Peers G, Pilon M, Ravet K. A program for iron economy during deficiency targets specific Fe proteins. Plant Physiol. 2018;186:596-610.

52. Zhu XF, Wang B, Song WF, Zheng SJ, Shen RF. Putrescine alleviates iron deficiency via NO-dependent reutilization of root cell-wall Fe in Arabidopsis. Plant Physiol. 2016;170(1):558-67.

53. Tsai HH, Schmidt W. Mobilization of iron by plant-borne coumarins. Trends Plant Sci. 2017;22(6):538-48.

54. Santos CS, Roriz M, Carvalho SMP, Vasconcelos MW. Iron partitioning at an early growth stage impacts iron deficiency responses in soybean plants (Glycine max L.). Trends Plant Sci. 2015;6:12.

55. Jin CW, You GY, He YF, Tang C, Wu P, Zheng SJ. Iron deficiency-induced secretion of phenolics facilitates the reutilization of root Apoplastic iron in red clover. Plant Physiol. 2007;144(1):278-85.

56. Chen WW, Yang JL, Qin C, Jin CW, Mo JH, Ye T, Zheng SJ. Nitric oxide acts downstream of auxin to trigger root ferric-chelate reductase activity in response to iron deficiency in Arabidopsis. Plant Physiol. 2010;154(2):810-9.

57. Lin $X Y$, Ye YQ, Fan SK, Jin CW, Zheng SJ. Increased sucrose accumulation regulates iron-deficiency responses by promoting auxin signaling in Arabidopsis plants. Plant Physiol. 2016;170(2):907-20.

58. Shanmugam V, Wang YW, Tsednee M, Karunakaran K, Yeh KC. Glutathione plays an essential role in nitric oxide-mediated iron-deficiency signaling and iron-deficiency tolerance in Arabidopsis. Plant J. 2015;84(3):464-77. 
59. Murgia I, Delledonne M, Soave C. Nitric oxide mediates iron-induced ferritin accumulation in Arabidopsis. Plant J. 2002;30(5):521-8.

60. Kaiser BN, Moreau S, Castelli J, Thomson R, Lambert A, Bogliolo S, Puppo A, Day DA. The soybean NRAMP homologue, GmDMT1, is a symbiotic divalent metal transporter capable of ferrous iron transport. Plant J. 2003;35(3):295304.

61. Zuchi S, Watanabe $M$, Hubberten H-M, Bromke M, Osorio S, Fernie AR, Celletti S, Paolacci AR, Catarcione G, Ciaffi M. The interplay between sulfur and iron nutrition in tomato. Plant Physiol. 2015;169(4):2624-39.

62. Astolfi S, Zuchi S, Neumann G, Cesco S, di Toppi LS, Pinton R. Response of barley plants to Fe deficiency and $\mathrm{cd}$ contamination as affected by $\mathrm{S}$ starvation. J Exp Bot. 2012;63(3):1241-50.

63. Zuchi S, Cesco S, Varanini Z, Pinton R, Astolfi S. Sulphur deprivation limits Fe-deficiency responses in tomato plants. Planta. 2009;230(1):85-94.

64. Buchner P, Stuiver CEE, Westerman S, Wirtz M, Hell R, Hawkesford MJ, De Kok $L$. Regulation of sulfate uptake and expression of sulfate transporter genes in Brassica oleracea as affected by atmospheric $\mathrm{H}_{2} \mathrm{~S}$ and pedospheric sulfate nutrition. Plant Physiol. 2004;136(2):3396-408.

65. Giehl RFH, Lima JE, von Wirén N. Localized iron supply triggers lateral root elongation in Arabidopsis by altering the AUX1-mediated auxin distribution. Plant Cell. 2012;24(1):33-49.

66. Wu T, Zhang HT, Wang Y, Jia WS, Xu XF, Zhang XZ, Han ZH. Induction of root $\mathrm{Fe}(\mathrm{III})$ reductase activity and proton extrusion by iron deficiency is mediated by auxin-based systemic signalling in Malus xiaojinensis. J Exp Bot. 2012;63(2):859-70

67. Matsuoka K, Furukawa J, Bidadi H, Asahina M, Yamaguchi S, Satoh S. Gibberellin-induced expression of Fe uptake-related genes in Arabidopsis. Plant Cell Physiol. 2014;55(1):87-98.

68. Wild M, Davière J-M, Regnault T, Sakvarelidze-Achard L, Carrera E, Lopez Diaz I, Cayrel A, Dubeaux G, Vert G, Achard P. Tissue-specific regulation of gibberellin signaling fine-tunes Arabidopsis iron-deficiency responses. Develop Cell. 2016;37(2):190-200.

69. Zhao M, Song A, Li P, Chen S, Jiang J, Chen F. A bHLH transcription factor regulates iron intake under Fe deficiency in chrysanthemum. Sci Rep. 2014; 4:6694.

70. Liu W, Karemera NJU, Wu T, Yang Y, Zhang X, Xu X, Wang Y, Han Z. The ethylene response factor AtERF4 negatively regulates the iron deficiency response in Arabidopsis thaliana. PLoS One. 2017;12(10):e0186580.

71. Martins S, Montiel-Jorda A, Cayrel A, Huguet S, Roux CP-L, Ljung K, Vert G. Brassinosteroid signaling-dependent root responses to prolonged elevated ambient temperature. Nat Commun. 2017;8(1):309.

72. Wang B, Li Y, Zhang W-H. Brassinosteroids are involved in response of cucumber (Cucumis sativus) to iron deficiency. Ann Bot. 2012;110(3):681-8.

73. Kobayashi T, Itai RN, Senoura T, Oikawa T, Ishimaru Y, Ueda M, Nakanishi H, Nishizawa NK. Jasmonate signaling is activated in the very early stages of iron deficiency responses in rice roots. Plant Mole Biol. 2016;91(4-5):533-47.

74. Kang HG, Foley RC, Oñate-Sánchez L, Lin C, Singh KB. Target genes for $\mathrm{OBP3}$, a dof transcription factor, include novel basic helix-loop-helix domain proteins inducible by salicylic acid. Plant J. 2003;35(3):362-72.

75. Rellán-Álvarez R, Giner-Martínez-Sierra J, Orduna J, Orera I, RodríguezCastrillón JÁ, García-Alonso Jl, Abadía J, Álvarez-Fernández A. Identification of a tri-iron(III), tri-citrate complex in the xylem sap of iron-deficient tomato resupplied with iron: new insights into plant iron long-distance transport. Plant Cell Physiol. 2010;51(1):91-102.

76. Pavlovic J, Samardzic J, Maksimović V, Timotijevic G, Stevic N, Laursen KH, Hansen TH, Husted S, Schjoerring JK, Liang Y. Silicon alleviates iron deficiency in cucumber by promoting mobilization of iron in the root apoplast. New Phytol. 2013;198(4):1096-107.

77. Covarrubias J, Rombolà A. Organic acids metabolism in roots of grapevine rootstocks under severe iron deficiency. Plant Soil. 2015;394(1-2):165-75.

78. Lichtenthaler HK. Chlorophylls and carotenoids: pigments of photosynthetic biomembranes. Meth Enzymol: Academic Press; 1987. p. 350-82.

79. Grusak MA. Whole -root iron(III)-reductase activity throughout the life cycle of iron-grown Pisum sativum L. (Fabaceae): relevance to the iron nutrition of developing seeds. Planta. 1995;197(1):111-7.

80. Sekiya J, Schmidt A, Wilson LG, Filner P. Emission of hydrogen sulfide by leaf tissue in response to L-cysteine. Plant Physiol. 1982;70(2):430-6.

81. Del Longo OT, González CA, Pastori GM, Trippi VS. Antioxidant defences under hyperoxygenic and hyperosmotic conditions in leaves of two lines of maize with differential sensitivity to drought. Plant Cell Physiol. 1993;34(7): 1023-8.
82. Wang GQ, Hao SS, Gao B, Chen MX, Liu YG, Yang JC, Ye NH, Zhang JH. Regulation of gene expression in the remobilization of carbon reserves in rice stems during grain filling. Plant Cell Physiol. 2017;58(8):1391-404.

83. Zhang N, Zhang HJ, Zhao B, Sun QQ, Cao YY, Li R, Wu XX, Weeda S, Li L, Ren $\mathrm{S}$. The RNA-seq approach to discriminate gene expression profiles in response to melatonin on cucumber lateral root formation. J Pineal Res. 2014;56(1):39-50.

84. Livak KJ, Schmittgen TD. Analysis of relative gene expression data using real-time quantitative PCR and the $2^{-\Delta \Delta} C T$ method. Methods. 2001;25(4): 402-8.

\section{Publisher's Note}

Springer Nature remains neutral with regard to jurisdictional claims in published maps and institutional affiliations.

\section{Ready to submit your research? Choose BMC and benefit from:}

- fast, convenient online submission

- thorough peer review by experienced researchers in your field

- rapid publication on acceptance

- support for research data, including large and complex data types

- gold Open Access which fosters wider collaboration and increased citations

- maximum visibility for your research: over $100 \mathrm{M}$ website views per year

At BMC, research is always in progress.

Learn more biomedcentral.com/submissions 